\title{
Über 25 mit Marmoreks Serum behandelten Fälle von Tuberkulose.
}

\author{
Von \\ Dr. F. Röver, \\ Assistenzarzt. \\ Mit 1 Tafel.
}

Eine Publikation ron Herrn Dr. Lew in (Stockholm) in der Berliner klinischen Wochenschrift 1905 Nr. 21 gab die Veranlassung, mit dem Antituberkulose-Serum Marmoreks Versuche an Kranken anzustellen. Auf die Anfrage betreffs der Erlangung des Serums zeigte Herr Dr. Marmorek mit ausserordentlicher Liebenswürdigkeit sich bereit, uns sein Serum zu einem grösseren Versuche gratis zur Verfügung zu stellen. Je nach der Ausdehnung der zurzeit ausgeführten Serumbehandlung trafen darauf wöchentlich Senảungen von 40,80 und 100 Fläschchen, à $5 \mathrm{ccm}$ Serum enthaltend, von Paris hier ein. Seit Ende Juli 1905, dem Beginn des Versuches, sind uns über 1100 Fläschchen Serum zugegangen. Für diese grosse Leistung, wie ferner für die ständige Bereitwilligkeit, uns in den verschiedensten Fragen Auskuntt zu erteilen, sei an dieser Stelle Herrn Dr. Marmorek unser Dank ausgesprochen.

Über die Herstellung und die Beschaffenheit des Serums ist von massgebender Seite geschrieben worden; hier sei nur das Wichtigste hervorgehoben. Über das Serum gibt Marmorek folgendes an. Im Gegensatz zu Koch, welcher zur Herstellung seines Tuberkulins die langsam gewachsenen Kulturen von Tuberkelbazillen verwandte, benutzt er zur Gewinnung seines Serums Tuberkelbazillen, welche er auf einem besonderen Nährboden innerhalb 24 bis 48 Stunden zum Wachstum gebracht hat. Diese "primitiven Kulturen" fabrizieren ein Gift, das verschieden von dem älterer Kulturen besonders die deletären Wirkungen im tierischen Organismus erzeugen soll. Mit 
diesem Gifte werden Pferde immunisiert, welche ein Antitoxin in ihrem Blute bilden und mit ihrem Serum das Antituberkulose-Serum liefern. Es handelt sich demnach bei der Behandlung mit dem Serum um eine passive Immunisierung. Da bei vielen Formen von Tuberkulose nicht Tuberkelbazillen in Reinkulturen die Krankheitserreger sind, sondern Mischinfektionen besonders mit Streptokokken bestehen, so ist auch darauf Bedacht genommen, gegen die Gifte der Streptokokken Antikörper in dem Serum zu schaffen. Marmoreks Serum enthält zweierlei Antitoxine, von Tuberkelbazillen und Streptokokken.

Über die Art der Applikation des Serums muss von Fall zu Fall entschieden werden. Marmorek schreibt zwei Arten der Behandlung vor, diejenige mit subkutanen Injektionen und die mit Darmeingiessungen. Ein dritter Modus vereinigt beide Behandlungsmethoden, indem Serien ron Einspritzungen mit solchen ron Darmeingiessungen abwechseln.

Bei subkutanen Injektionen werden $5 \mathrm{ccm}$ Serum als Einzeldosis jeden zweiten Tag drei Wochen lang eingespritzt, es folgt dieser Serie ron 10 Einspritzungen eine Ruhepause ron drei Wochen. Nach dieser Zeit werden die Einspritzungen in derselben Weise wie zu Anfang wieder aufgenommen, worauf nach der zweiten Serie von 10 Einspritzungen abermals eine Pause von drei Wochen eintritt und so fort. Ganz streng lassen sich zuweilen die Zeiten nicht innehalten, oft wird es nötig sein, dass der Patient auch während der Einspritzungen eine zwei- oder dreitägige Pause macht; es kommt da sehr auf die Empfindlichkeit der Kranken an. Im allgemeinen werden 10 Einspritzungen ohne Unterbrechung gut vertragen. Wer mit der Serumbehandlung vertraut ist, wird in manchen Fällen nach seinem Ermessen von der gegebenen Vorschrift abweichen, so baben wir zuweilen die Pause verkürzt, zuweilen die Dosis verdoppelt usw., im grossen und ganzen jedoch an der Zeiteinteilung festgehalten.

Die zweite Art der Applikation des Serums besteht in hohen Darmeingiessungen durch die Darmsonde. Morgens wird ein Reinigungsklistier gegeben und nach erfolgter Defäkation durch die möglichst hoch eingeführte Darmsonde $5-10 \mathrm{ccm}$ Serum eingespritzt. Durch das Nachspritzen von 10-15 ccm lauwarmen Wassers vermeidet man, dass ein Teil des Serums mit dem Entfernen der Sonde verloren geht. Diese Darmeingiessungen werden täglich gemacht und können beliebig lange fortgesetzt werden.

Die Kombination dieser beiden Behandlungsmethoden wird später wahrscheinlich die zumeist geübte Applikationsart sein. Wir haben sie verschiedentlich ausgeführt. 
Welcher Körperteil eignet sich am besten für die Injektion? Da grössere Mengen, $5 \mathrm{ccm}$, eingespritzt werden, sind solche Stellen die geeignetsten, an welchen die Haut sich leicht in Falten abheben lässt. Vorgeschlagen sind die Bauchdecken, die Lenden und Oberschenkel. Wir haben fast durchweg die Aussenseite des Oberschenkels gewählt. Injektionen am Bauche verursachten bei starkem Husten oft erhebliche Schmerzen, während die Gehstörungen, welche zuweilen infolge der Einspritzungen am Bein entstanden, bei der streng durchgeführten Liegekur in freier Luft nicht von Belang waren.

Die Stelle für die Injektion wurde sorgfältig abgeseift, mit Äther and Sublimat keimfrei gemacht, Spritze und Kanüle direkt vorher ausgekocht. Nach der Einspritzung wurde die Einstichstelle der Haut mit Heftpflaster bedeckt, Patient blieb darauf mindestens eine Stunde ruhig zu Bett liegen.

Um die eventuellen Fiebersteigerungen nach den Injektionen genau beobachten zu können, wurden die Einspritzungen morgens zwischen 9 und $10 \mathrm{Uhr}$ gemacht. Die Temperatur der Kranken wurde $4 \mathrm{mal}$ am Tage gemessen, um $7 \mathrm{Uhr}$ morgens, um $12 \mathrm{Uhr}$ vor der Mahlzeit, um 5 Uhr und abends $8 \mathrm{Uhr}$. In den beigegebenen Fieberkurven sind nur die niedrigste (fast ausnahmslos Morgentemperatur) und die höchste Temperatur angegeben.

Um den psychischen Einfluss auf die Temperatur bei der Beurteilung ausschalten zu können, wurde bei der Mehrzahl der Fälle zwei Tage vor der ersten Einspritzung eine Injektion ron $5 \mathrm{ccm}$ physiologischer Kochsalzlösung gemacht. Bei einigen beobachteten wir eine Temperaturerhöhung um einige Zehntel danach.

Bevor wir zu den Krankengeschichten übergehen, bedarf es einer kurzen Angabe, unter welchen Verhältnissen die Kranken auf unserer Tuberkulosestation behandelt werden. Wir sind hier in Bremen in der glïcklichen Lage, ein Luftkurhaus zu besitzen, das allen modernen Ansprüchen, welche an ein Tuberkulosehaus gestellt werden, entspricht. Das Haus hat genau die Nord-Süd-Richtung, an der Ostseite des Hauses befinden sich freie Veranden, an der Westseite dagegen gedeckte offene Liegehallen. Die Kranken liegen den ganzen Tag, sei es auf dem Liegestuhle, sei es im Bette, bis tief in den Herbst hinein in frischer Luft. Selbst fiebernden Kranken, sobald das Fieber nicht $38,5-39,0^{\circ}$ überschreitet, wird die Freiluftbehandlung in vollem Masse zuteil.

In der Ernährung der Kranken bildet die Milch einen Hauptfaktor, alkoholische Getränke werden nicht gegeben.

Die mit Serum behandelten Patienten erhielten abgesehen vom 
Morphium und Liq. amon. anis. keine weiteren Medikamente, in chirurgischen Fällen wurde zum Verband aseptische Gaze verwandt.

Was nun das Krankenmaterial selbst anlangt, so befinden sich unter den 25 beschriebenen Fällen alle Stadien der Lungenschwindsucht, einige Fälle von Tuberkulose der Drüsen, der Haut, der Knochen und des Harnapparates.

Im folgenden sind, wie die Zusammenstellung ergibt, die Krankengeschichten geordnet nach Art der Krankheit, der Serumbehandlungsweise und nach dem Erfolge der Behandlung. Auf den beigefügten Fieberkurven sind die Injektionen durch Striche angegeben.

1. Lungentuberkulose mit subkutanen Injektionen behandelt

a) wesentliche Besserungen Fall 1-4,

b) keine wesentliche Veränderung Fall 5-7,

c) ungünstiger Ausgang Fall 8-11.

2. Lungentuberkulose mit Darmeingiessungen behandelt:

a) günstiger Verlauf Fall 12,

b) keine wesentliche Änderung Fall 13--15,

c) ungünstiger Ausgang Fall 16,

3. Drüsentuberkulose Fall 17-20,

4. Hauttuberkulose Fall 21,

5. Knochentuberkulose Fall 22 u. 23,

6. Blasentuberkulose Fall 24,

7. Blasen- und Nierentuberkulose Fall 25.

\section{Krankengeschichten.}

\section{Lungentuberkulose mit subkutanen Injektionen behandelt.}

Fall 1. Gustav P., Weber, 25 Jahre.

Eltern und Schwester gesund. Pat. ist früher immer gesund gewesen, ist seit neun Wochen krank, hat Husten und Schmerzen vorn auf der rechten Seite. Bis zum 13. Mai hat Pat. gearbeitet, ist seit einer Woche bettlägerig. Nachts wenig Schlaf, starke Schweisse. Aufnahme 20. V. 1905.

Ziemlich blasser, mässig genährter junger Mann. Beide Lungenspitzen gedämpft, rechte mehr als linke, über der rechten Spitze Bronchialatmen und reich. liche Rasselgeräusche, über der linken Spitze verschärftes Atmen mit einzelnen Rasselgeräuschen. Sputum spärlich, Tuberkelbazillen vorhanden. Urin frei von Eiweiss und Zucker.

Das Fieber $39,8^{\circ}$ sank in acht Tagen zur normalen Temperatur; Pat. ist seitdem stets fieberfrei geblieben. 23. V. mässig starke Hämoptöe.

Nach den ersten fünf Wochen seines Aufenthaltes in der Anstalt verschwanden die Nachtschweisse. Seit Ende Juni wurde die linke Lunge frei befunden. Ende Juli fand sich über der rechten Lunge Spitzendämpfung bis zur zweiten Rippe, Bronchialatmen mit Rasseln, hinten bis zum Schulterblattwinkel hörbar. Nun wurde die Seruminjektionskur eingeleitet. 


29. Juli bis 16. August 1njektion $1-10$ à 5 ccm
28. August " 18. September " $11-20$ à 5,
17. Oktober " 15. November , $21-30$ à 5 ,

2. Dezember Entlassung.

Die Einspritzungen wurden sehr gut vertragen, Temperaturanstiege sind nicht vorgekommen. Das Sputum wurde allmählich weniger, am 20. VIII., 5. IX. und 1. XII. ausgeführte Sputumuntersuchungen liessen Tuberkelbazillen nicht mehr auffinden. Die Dämpfung über der rechten Spitze war am I. XII. vorn nicht mehr nachweisbar, ebenso waren die Rasselgeräusche verschwunden. Hinten wies die Schmalheit des Krönigschen Feldes auf der rechten Schulter auf eine Spitzenaffektion hin. Hier waren verschärftes Atmen und einzelne wenige Rasselgeräusche auskultatorisch wahrnehmbar. Das Befinden des Pat. ist stets gut gewesen, das Körpergewicht ist von 108 Pfund auf 134 Pfund gestiegen. Finer Abnahme von 2 Pfund in der letzten Woche ist wohl keine Bedeutung beizulegen.

Pat. verliess am 2. XII. sehr gut gebessert die Anstalt, um in einer Lungenheilanstalt im Harz zur weiteren Ausheilung eine Kur durchzumachen.

Fall 2. Emil M., Heizer, 26 Jahre.

Eltern früh gestorben, Todesursache unbekannt. Pat. früher immer gesund gewesen, hat seit acht Jahren als Heizer zur See gefahren, hat seit vier Wochen Husten mit gelblich-grünem Auswurf, hauptsächlich morgens. Pat. füblt sich matt, hat an Gewicht abgenommen. Zeitweilig Nachtschweisse. Aufnahme 29. VII. 1905 .

Status. Kräftiger Mann in leidlichem Ernährungszustande, am Cucullarisrande beiderseits einige Drüsen fühlbar, linke Schulter hängt etwas, linke Brustseite bleibt bei der Atmung etwas zurück.

Rechte Lunge: Spitze gedämpft, daselbst bronchiales Atmen mit einigen trockenen Rasselgeräuschen, weiter abwärts verschärftes Atmen.

Linke Lunge: Mässige Spitzendämpfung bis abwärts zur zweiten Rippe, hinten bis zur Spina scapulae, im Bereiche der Dämpfung bronchiales Atmen mit etwas klingendem Rasseln, unterhalb der Klavikula zahlreiche mittelblasige Rasselgeräusche, nach unten hin spärlicher werdend.

Bauchorgane ohne besonderen Befund; Urin frei von Eiweiss und Zucker. Sputum nicht reichlich, Tuberkelbazillen vorhanden. Pat. ist fieberfrei.

Die Seruminjektionskur wurde eingeleitet, jeden zweiten Tag wurden $5 \mathrm{ccm}$ Serum subkutan injiziert. Pat. vertrug die ersten Einspritzungen, ohne irgendwelche Reaktion zu zeigen. Nach der fünften Injektion stellte sich ein an dem ganzen Rumpf und an den Beinen verbreitetes feinfleckiges Exanthem ein; ausserdem bestand seit zwei Tagen eine Angina mit $38,2^{\circ}$ Fieber. Kieferdrüsen waren geschwollen. Alle diese Erscheinungen boten das Bild wie bei einer Scharlach. erkrankung. Mit der Besserung der Angina sank das Fieber während fünf Tagen zur normalen Temperatur. Das Exanthem hielt drei Tage an, verschwand dann aber, obgleich nach den drei Tagen die Einspritzungen wieder fortgesetzt wurden. Ein Exanthem hat sich später nicht wieder gezeigt. Während der ganzen Zeit seines Aufenthaltes in der Anstalt ist Pat. fieberfrei geblieben, die Temperatur blieb gewöhnlich dicht unter $37,0^{\circ}$, einmal wurde $37,3^{\circ}$ erreicht. Reaktionen an der Impfstelle, welche zu Unbequemlichkeiten führen, sind bei ihm kaum vorgekommen, hingegen ist eine Empfindlichkeit gegen Injektionen stark hervorgetreten, sobald eine Vene verletzt und ein Teil des Serums in dieselbe eingespritzt war. Obgleich bei den Injektionen die Nadel erst weit unter die Haut geschoben, dann ein wenig wieder zurückgezogen wurde, konnten intravenöse Injektionen 
nicht immer ganz vermieden werden. Pat. bekam bei solchen Vorkommnissen - sie ereigneten sich viermal - sehr starken Blutandrang zum Kopf, grosses Angstgefühl und heftigen Husten. Nach einigen Minuten war ein solcher Anfall vorüber; über der Lunge liessen sich darauf noch nach zwei Tagen leise Rasselgeräusche auskultatorisch wahrnehmen. Es handelte sich unzweifelhaft um embolische Prozesse in der Lunge, welche diese Erscheinungen hervorgerufen hatten.

Zeiteinteilung für die Injektionen war folgende:
31. Juli
bis 20. August
Injektion $1-10$ à $5 \mathrm{ccm}$
28. August
18. September
" $11-20$ à 5 ,
17. Oktober, 13. November
,
$21-29$ à 5 ,

7. Dezember Entlassung.

Schon während des August sind die Nachtschweisse gänzlich geschwunden, Auswurf wurde ganz spärlich, Pat. brauchte nur morgens einige Ballen auszuhasten.

Die Dämpfung über der linken Lungenspitze wurde kleiner. Auskultatorisch Bronchialatmen, verlängertes Exspirium, auf der Höhe des Inspiriums ein leises Knacken hörbar, über den unteren Partien der Lunge mässiges Knistern. Über der rechten Lungenspitze kein Katarrh wahrnehmbar. Später, Mitte Oktober, war der Katarrh der linken unteren Lungenpartien beseitigt, nur in der linken Lungenspitze noch einzelne Rasselgeräusche hörbar. blieben.

Die Bazillen sind bis Ende der Behandlung im Auswurf nachweisbar ge.

Pat. hat sich sehr gut erholt, sein Gewicht ist von Ende Juli bis Ende Oktober von 109 auf 120 Pfund gestiegen und mit kleiner Schwankung in der Höhe geblieben.

Am 7. XII. wurde Pat. aus der Anstalt entlassen, um zur weiteren Ausheilung eine Kur in einer Lungenheilanstalt im Harz durchzumachen.

Fall 3. Christian v. H., Schlosser, 21 Jahre.

Hereditäre Belastung nicht nachgewiesen, Pat. hustet seit diesem Sommer ohne Auswurf, leidet an Nachtschweissen, am 6. X. plötzlich Bluthusten (etwa ein Esslöffel voll Blut), bis zum 7. X. hat Pat. gearbeitet. Aufnahme 9. X. 1905.

Status. Stark gebauter, gut genährter junger Mann von etwas untersetzter Figur, am Halse starke Drüsenschwellung.

Über der linken Lungenspitze Dämpfung der Fossa supraclavicul. und Fossa supraspinata, im Bereiche der Dämpfung bronchiales Atmen und mässiges Rasseln.

Bauchorgane ohne Befund. Urin frei. Auswurf spärlich, enthält Tuberkelbazillen. Fieber siehe Temperaturkurve.

Die Seruminjektionskur wurde am 20. X. begonnen. Da nach der ersten Injektion an demselben und dem folgenden Tage ein Temperaturanstieg erfolgte, wurde zunächst von weiteren Injektionen Abstand genommen. Ob das Fieber tatsächlich durch die Injektion verursacht war, ist bei Betrachtung der Temperaturen an den früheren und späteren Tagen schwer zu entscheiden. Wir möchten nicht die Einspritzung als Ursache des Temperaturanstieges ansehen, da bei den vom 31. X. ab fortgesetzten Injektionen eine allmähliche Entfieberung eintrat. Pat. hat 10 Injektionen, à $5 \mathrm{ccm}$, erhalten. Was den Krankheitsverlauf anbetrifft, so hat während der hohen Temperaturen ein Fortschritt des Prozesses stattgefunden, was sich anfangs durch vermehrte Rasselgeräusche, später durch vergrösserte Dämpfung kund gab. Als Pat. die Anstalt am 14. XII. verliess, um eine Kur im Harz durchzumachen, bestand leichte Dämpfung bis zur zweiten Rippe und Spina scap. In der Spitze selbst waren nur einzelne Rasselgeräusche, 
weiter abwärts etwas zahlreichere hörbar, die unteren Partien der linken Lunge und die rechte Lunge waren frei.

Die Drïsen am Halse waren nicht sonderlich geschwollen. Auswurf minimal, enthielt Bazillen. Nachtschweisse verschwunden.

Gewichtszunahme um 5 Pfund. Pat. fühlte sich kräftiger. Inwioweit in diesem Falle eine Serumwirkung in Frage kommt, lässt sich nicht sagen. Die Prognose scheint nicht ungünstig.

Fall 4. Auguste O., Dienstmädchen, 21 Jahre.

Frblich belastet, seit 14 Tagen Husten und Auswurf. Aufnahme 13. VI. 1905.

Über der rechten Lungenspitze ganz geringe Scballabschwächung, über beiden Lungenspitzen Rasseln und Pfeifen. Im Sputum Tuberkelbazillen vorhanden. Gegeu Ende Juni mit dem Ansteigen der Temperatur trockene Pleuritis. Pat. fiebert bedeutend mit Remissionen von $3^{1 / 2}$ Grad, Fieber bald etwas nachlassend, bald wieder stark remittierend, s. Kurve.

Pat. wurde am 24. VII. von dem Krankensaal der medizinischen Abteilung ins Luftkurhaus verlegt. Auf diese Weise war es möglich, die Kranke an guten Tagen im Bette auf den Balkon ins Freie $z u$ bringen. In den nun folgenden Tagen trat mit Beginn der Freiluft- und Serumbehandlung ein kolossaler Umschwung in dem Krankheitsverlaufe ein; es schien so, als wenn die Kranke von nun an sich erholte.

Der Status war folgender: Über dem rechten Oberlappen Dämpfung der Spitze bis an den unteren Rand der Klavikula, hinten bis zur Spina scap. In der Spitze trockene, über der zweiten Rippe feuchte Rasselgeräusche, weiter abwärts verschärftes Atmen mit einzelnen Rasselgeräuschen, untere Lungenpartien frei. Über der linken Lunge normaler Lungenschall, auskultatorisch in der Spitze trockene Geräusche hörbar, bis zur dritten Rippe abwärts abnehmend. Die anderen Organe ohne besonderen Befund. Auswurf ziomlich reichlich, an Tage 1/2 Becher voll. Injektionen wechselten mit Pausen ab.
29. Juli
bis 16. August
Injektion $1-10$ à $5 \mathrm{ccm}$
28. August
22. September
17. Oktober
"18. September
3. Oktober $10 \mathrm{~S}$. Einläufe
"11. November Injektion $21-30$ à $5 \mathrm{ccm}$.

Während der ersten 10 Einspritzungen steigt das Fieber zumeist bis $37,8^{\circ}$. Der Auswurf nimmt zuerst an Menge zu, wird aber vom 2. August weniger, vom 10. August bedeutend spärlicher. Nach den 10 Injektionen sehen wir die Temperatur sich in fast normaler Weise um $37^{\circ}$ bewegen. Pat. schläft des Nachts ohne zu husten.

Über der linken Lunge ist an Stelle des Katarrhs nur verschärftes Atmen ohne Rasselgeräusche zu hören. Als Residuum der Pleuritis ist über dem rechten Unterlappen hinten eine drei Finger breite gedämpfte Zone entstanden; über der rechten Spitze besteht noch Dämpfung und Rasseln.

Mit Wiederaufnahme der Injektionen wird die Temperatur weniger konstant, nach Injektion 16 (9. IX.) folgt ein Fieberanstieg bis $39,4^{\circ}$, worauf dann Entfieberung eintritt. Ob dieser plötzliche Anstieg durch die Einspritzung veranlasst ist, ist zweifelhaft, da drei Tage nach der 20. Injektion wieder eine kurze Fieberattacke vorkommt, deren Akme und Sinken zeitlich mit Serumklistieren zusammenfallen. Dieses Ietzte Fieber kann nicht durch das Serum veranlasst sein, da es schon einen Tag vorher beginnt. Mit dem Sinken des letzten Fiebers ist die definitive Entfieberung eingetreten. 
Seit 1. Oktober hat Pat. keinen Auswurf mehr, es war nicht möglich, zur Untersuchung noch Auswurf zu bekommen.

Vom 17. Oktober folgte noch die dritte Serie von Einspritzungen, welche ohne Nachteil vertragen wurde.

Die Schlussuntersuchung ergab noch Dämpfung der rechten Lungenspitze und hier noch ein klein wenig Rasseln.

Ein getreues Abbild des ganzen Krankheitsverlaufes gibt die Gewichtskurve, welche wir nebenbei abzeichnen.

Am 11. XI. wurde Pat. wach ihrer Heimat bedeutend gebessert entlassen.

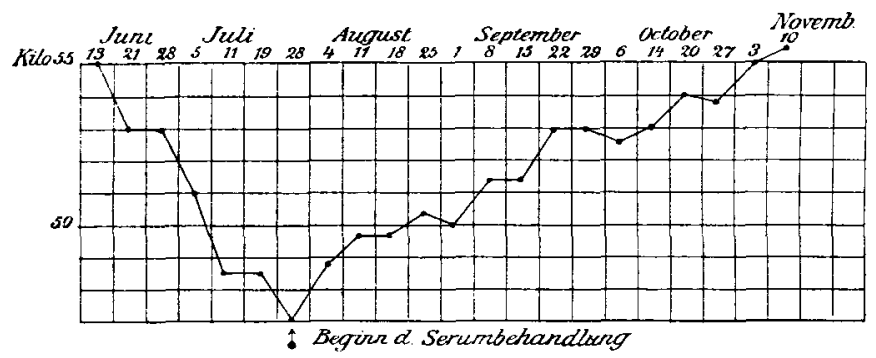

Fall 5. Luigi N., Terrazzuarbeiter, 31 Jahre.

Pat. fühlt sich seit 14 Tagen krank, hat Husten und zuweilen Auswurf, ist früher immer gesund gewesen. Hereditäre Belastung nicht nachgewiesen. Aufnahme 1. VIII. 1905.

Status: Kräftig gebauter Mann in gutem Ernährungszustande.

Beide Klavikulargruben eingezogen, rechte Seite bleibt bei der Atmung zurück.

Die rechte Lungenspitze ist vorn bis zur zweiten Rippe, hinten bis zur Spina scap. gedämpft, hier bronchiales Atmen und kleinblasiges Rasseln, weiter abwärts verschärftes Atmen und einzelne Rasselgeräusche.

Herz und Bauchorgane normal, Urin frei. Sputum in geringer Menge, Bazillen reichlich.

2. August bis 26. August Injektion $1-10$ à $5 \mathrm{ccm}$.

28. August Injektion 11.

29. August bis 7. September Serumeinlauf $1-10$.

11. September Entlassung.

Fieberverlauf s. Kurve. Das Fieber scheint durch das Serum nicht beeinflusst zu sein.

Die Injektionen werden gut vertragen. Die Dämpfung über der Lunge ist unverändert geblieben, doch haben die Rasselgeräusche an Zahl nachgelassen.

Das körperliche Befinden war im übrigen gut. Pat. erholte sich trotz des andauernden Fiebers. Sein Körpergewicht stieg von 130 auf 140 Pfund.

11. IX. Pat. wurde auf seinen Wunsch hin entlassen, da er in seine Heimat nach Italion zurückkehren wollte.

In dem geringen Auswurf fanden sich zum Schluss Bazillen in mässiger Menge.

Fall 6. Walter H., Dekorationsmaler, 22 Jahre.

Mutter an Lungentuberkulose gestorben. Pat. hat gedient, gibt an, vor drei Jahren nach einem Stoss vor die Brust Bluthusten bekommen zu haben, hat dann 
ein Jahr später wieder Bluthusten gehabt. Pat. hat trockenen Husten, nur spärlichen Auswurf. Aufnahme 2. VIII. 1905.

Zart gebauter Mann, Fettpolster stark geschwunden, blasse Gesichtsfarbe. Linke Brustseite abgeflacht, bleibt bei der Atmung zurück; über der linken Lungenspitze Schalldämpfung bis zur dritten Rippe, in der Spitze bronchiales Atmen, von der zweiten Rippe abwärts mittel- und kleinblasige Rasselgeräusche, nach unten hin abnehmend. Hinten Dämpfung abwärts bis zur Mitte der Skapula, daselbst Bronchialatmen, kein Rasseln. Über der rechten Lunge besteht Dämpfung vorn bis zur zweiten Rippe, hinten bis Mitte der Skap., über der ganzen rechten Lunge Rasseln, in der Spitze Bronchialatmen.

Herztätigkeit beschleunigt, Herztöne rein. Sputum spärlich, Tuberkelbazillen spärlich vorhanden. Urin frei. Behandlung vom 2. VIII. bis 5. IX. 14 Injektionen à $5 \mathrm{ccm}$ hat Pat. erhalten. Fieberverlauf s. Kurve.

Anfangs scheint das Fieber schwinden zu wollen, dann ein Tag nach der dritten Injektion steigt die Temperatur wieder auf $38,1^{\circ}$ an und senkt sich bei fünf Injektionen bis $37,4^{\circ}$. Nach fünf Tagen Pause; bei Wiederaufnahme der Injektionen erneuter Anstieg auf 38,1 ${ }^{\circ}$, dann keine definitive Entfieberung. Leider musste Pat. die Anstalt verlassen, ohne dass eine Besserung der Lunge stattgefunden hatte. Der Schlussbefund wich nicht wesentlich von dem Anfangsbefunde $a b$. Das körperliche Befinden hat te sich gebessert, das Gewicht war von 93 Pfund auf 96 Pfund gestiegen.

Die Sputummenge war die gleiche geringe geblieben, Bazillen waren bei zwei Untersuchungen spärlich, bei der letzten reichlich nachweisbar. Wir haben mit diesem Fall ein Beispiel aus dem zweiten Stadium der Lungentuberkulose, das uns bei einmonatlicher Behandlung keine nennenswerte Besserung zeigt.

Fall 7. Bernhard St., Tischler, 34 Jahre.

Hereditäre Belastung nicht nachgewiesen, mit 17 Jahren Typhus durchgemacht, sonst immer gesund gewesen. Seit 1 Jahr Husten, seit ${ }^{1} 4 \mathrm{Jahr}$ Auswurf, keine Nachtschweisse. In letzter Zeit Brustschmerzen.

Status: Kräftig gebauter, leidlich genährter Mann mit guter Muskulatur.

Über der linken Lungenspitze Dämpfung der Fossa supraclavic. und Fossa supraspinata, im Bereiche der Dämpfung und darüber hinaus bis zur dritten Rippe beim Inspir. fast klingendes Rasseln. Rechts ist die Lungenspitze leicht gedämpft, hier Atmen verschärft und einzelne Rasselgeräusche hörbar.

Die übrigen Organe ohne besonderen Befund. Sputum spärlich, enthält massenhaft Tuberkelbazillen. Abgesehen von einem Temperaturanstiege auf $38,1^{\circ}$ am vierten Tage jst Patient immer feberfrei gewesen. Am sechsten Tage Beginn der Seruminjektionskur. Pat. erhielt 11 Einspritzungen, à $5 \mathrm{ccm}$, hat dieselben gut vertragen ohne lokale Reaktion und Temperaturerhöhung. Das Kasseln über der Lunge war bald mehr, bald weniger hörbar, doch blieb als ständige Besserung das Schwinden des Katarrhs der rechten Lunge. Links blieb derselbe Befund. Körperlich hat Pat. sich gut erholt, sein Gewicht stieg von 108 auf 117 Pfund.

Leider entzog sich eine weitere Besserung unserer Beobachtung, da Pat. am 19. X. eine Kur im Harz begann.

Fall 8. Johann M., Kellner, 27 Jahre.

Mutter angeblich an Asthma gestorben. Pat. hat seit sechs Wochen Husten mit Auswurf und Stechen in der Seite, muss nachts stark schwitzen. Am 18. VII. Bluthusten. Pat. ist stark abgemagert. Aufnahme 19. VII. 1905.

Beiträge zur Klinik der Tuberkulose. Bd. V. H. 3. 
Status: Blasser, schwächlich gebauter, abgemagerter Mann. Rechte Seito bleibt bei der Atmung zurück. Über der rechten Lungenspitze besteht Dämpfung mit tympanitischem Beiklang bis zur zweiten Rippe. Hinten Dämpfung der Fossa supraspinata. Auf der ganzen rechten Seite hört man mittel- und grossblasiges Rasseln. Links ist nur die Spitze gedämpft, hier kleinblasiges Rasseln. Starke Nachtschweisse, reichlich Auswurf mit Tuberkelbazillen.

Pat. fiebert mit Tagesschwankungen von $37,0^{\circ}$ bis $38,5^{\circ}$. Am ersten Tage hier leichte Hämoptöe. Beginn der Serumbehandlung am 29. VII. Temperatur s. Kurve.

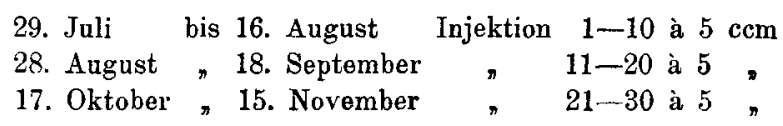

Pat. ist nock in Behandlung.

Das Fieber ist in dem langen Krankheitsverlaufe nicht beseitigt, der Auswurf ist reichlicher geworden, Pat. hat stark unter Nachtschweissen zu leiden.

Die Dämpfung über der rechten Lunge ist bis zur dritten Rippe fortgeschritten, auf dieser ganzen Seite sind reichlich grossblasige, in der linken Spitze kleinblasige Rasselgeräusche zu hören. Das Gewicht hat abgenommen von 96 auf 88 Pfund. Prognose ist seblecht.

Bemerkenswert ist die zwei Tage vor der ersten Seruminjektion gemachten subkutanen Kochsalzinjektionen, auf welche Pat. mit $38,3^{\circ}$ Fieber reagierte, während die erste Seruminjektion keine hohe Temperatur zur Folge hatte (s. Kurve).

Fall 9. Heinrich E., Kutscher, 23 Jahre.

Eltern gesund, Bruder lungenkrank. Pat. hatte vor sechs Jahren ein Ohrleiden mit starker Eiterung. Diese hat auch nach Ohraufmeisselung weiter bestanden. In letzter Zeit musste Pat. wenig husten, bis vor zwei Tagen hat er als Kutscher seine Arbeit getan. Aufnahme am 12. IX. 1905.

Status: Ziemlich blasser, schlecht genährter junger Mann. Über den Lungenspitzen vorn Dämpfung nicht nachweisbar, dagegen hinten schon deutlich, über beiden Lungenspitzen hört man viel klingendes Rasseln, links mehr als rechts.

Rechtes Obr eitert stark, Trommelfell geschwunden. Im Urin deutliche Spuren von Eiweiss. Auswurf spärlich, Tuberkelbazillen masseniaft vorhanden. Fieber s. Temperaturkurve. Gewicht 101 Pfund. Am fünften Tage wurde die Seruminjektionskur eingeleitet.

Bereits am 19. IX. besteht Dämpfung über der linken Lungenspitze vorn bis zur zweiten Rippe, hinten bis zur Spin. scap. hinabreichend. Über der ganzen linken Lunge Rasseln. Diese Rasselgeräusche haben sich nach weiteren 14 Tagen über beide Lungenflügel verbreitet, links mehr grossblasig, rechts mehr mittelblasig.

Vom 6. X. machten sich Gehirnerscheinungen bemerkbar. Pat. wurde verwirrt, redete konfus. Die Finger der ruhig gehaltenen Hände machten häufig Einzelzuckungen.

9. X. Cheyne-Stokessches Atmen.

12. $\mathrm{X}$. Exitus. Sektion: In der linken Lungenspitze eine walnussgrosse Kaverne, weiter im Zentrum des Mittellappens käsige Degeneration. Die übrige linke und die ganze rechte Lunge zeigen das Bild einer käsigen Pneumonie. In Nieren, Milz und Leber zahlreiche Knötchen. An der Basis des Gehirns eitrig sulziges Exsudat, in der Umgebung der Artt. fossae Sylvii zahlreiche Knötchen. Pat. hat neun Seruminjektionen erhalten. 
Wenn wir die Kurve betrachten, so sehen wir, dass das Fieber dem gallopierenden Verlaufe der Krankheit völlig entspricht. Die Seruminjektionen hatten nicht vermocht, die überaus rasche Ausbreitung des Krankheitsprozesses im mindesten aufzubalten. Es handelte sich in diesem Falle um eine Reininfektion von Tuberkelbazillen, wenn auch die Kurve mehr das Bild wie bei septischem Fieber gibt. E's bestand sehr wenig Auswurf, im mikroskopischen Präparate trat der Nebenbefund an anderen Bakterien gegenüber der grossen Anzabl von Tuberkelbazillen völlig zurück, obgleich keine ausgebildete Larynxphthise vorhanden war. In der Hoffnung, den Körper noch energischer zu entgiften, wurden bei den drei letzten Injektionen jedesmal $10 \mathrm{ccm}$ Serum eingespritzt, doch ohne Erfolg.

Fall 10. Heinrich G., Arbeiter, 34 Jahre.

Mutter an Phthise gestorben. Pat. seit ${ }^{1} / 2$ Jahr zu Hause wegen Lungenkatarrh behandelt, früher immer gesund gewesen. Pat. leidet stark an Nachtschweissen, zuweilen ist Blut im Auswurf gewesen.

Status: Blasser, schlecht genährter, engbrüstiger Mann. Dämpfung über dem rechten Oberlappen bis hinab zur dritten Rippe und Spina scap., daselbst Bronchialatmen mit mässig viel Rasseln. Links Spitzendämpfung, dort kein Rasseln. Pat. spricht heiser. Es besteht Ulcus der Kehlkopfhinterwand.

Im Sputum Tuberkelbazillen reichlich vorhanden. Im Urin ${ }^{1 / 4} \%$ Albumen nach Esbach. Fieber s. Temperaturkurve.

Pat. hat in zwei Monaten 17 Injektionen, à 5 ccm Serum, erhalten. Der Prozess in den Lungen schritt stürmisch fort, das Fieber liess sich nicht im mindesten verringern.

Nach einer Woche liessen sich perkutorisch Kavernen feststellen, der Auswurf wurde reichlicher.

Pat. wurde bald vollständig stimmlos, verfiel zusehends, magerte aufs äusserste ab: das Gewicht fiel in zwei Monaten von 102 auf 92 Pfund.

Am 22. X. hatte sich links ein Pneumothorax gebildet, am 23. X. Exitus.

Sektion: In dem rechten Oberlappen sehr grosse Kavernen, im Unterlappen nur noch ein ganz kleiner Teil von erhaltenem Iungengewebe. Die linke Lunge absolut vereitert, auf ein kleines Volumen geschrumpft. In dem Pleuraraum grosser Pneumothorax, verursacht durch eine Perforation in der Lungenspitze.

Im Darm zahlreiche Geschwüre. Nieren hyperämisch, geschwollen.

Es zeigt uns dieser Fall, dass etwas weiter vorgeschrittene Prozesse in der Lunge mit Affektion des Kehlkopfes von dem Serum nicht mehr aufgehalten werden.

Fall 11. Heinrich R., Küper, 28 Jahre.

Hereditäre Belastung nicht nachgewiesen. Pat. ist seit ${ }^{3} / 4$ Jahr heiser, hat seitdem Husten und Auswurf, ist in letzter Zeit abgemagert, hat seit einigen Tagen Durchfälle, muss sehr häufig Urin lassen. Aufnahme 2. VIII. 1905.

Status: Mittelgrosser Mann von schwächlichem Knochenbau, ziemlich abgemagert, Gesichtsfarbe blass. Rechte Brustseite abgeflacht, ausgedehnte Dämpfung über beiden oberen Lungenlappen, daselbst Bronchialatmen, aber nur wenig Katarrh.

Auf der Hinterwand des Rachens ein $6 \mathrm{~mm}$ im Durchmesser haltendes Ulcus sichtbar, aryepiglottische Falten stark verdickt, Ulcus der Stimmbänder.

Sputum spärlich, Tuberkelbazillen reichlich vorhanden. Leib weich, keine häufigen Durchfälle. Urin muss in kleinen Pausen gelassen werden. Pat. kann zurzeit nur $50 \mathrm{ccm}$ Urin halten. Der Urin ist trübe, enthält reichlich Eiterkörperchen und säurefeste Stäbchen, letztere in typischer Nesteranordnung. Der mit den im Urin gefundenen Bazillen angestellte Tierversuch bestätigte die Dia- 
gnose Tuberkulose. Der Eiweissgehalt des Urins war ${ }^{1}{ }^{0}{ }_{00}$ nach Esbach. Die klinische Diagnose lautete demnach auf Tuberkulose des Pharynx, des Larynx, beider Lungen, des Darmes, der Nieren und der Blase.

Trotz dieser ausgedehnten Tuberkulose machte Pat. einen relativ frischen Eindruck, was dazu führte, einen Versuch mit dem Serum anzustellen. Pat. erhielt 16 Injektionen a $5 \mathrm{ccm}$. Das Fieber blieb bei seinen Schwankungen zwischen $37^{\circ}$ und $39^{\circ}$, nur zeitweise stieg es nur bis $38^{\circ}$. Pat. verfiel und starb am 17. IX. Die Sektion bestätigte, was klinisch festgestellt war.

\section{Lungentuberkulose mit Darmeingiessungen behandelt.}

Fall 12. Fritz H., Hotelier, 27 Jahre.

Eereditäre Belastung nicht nachgewiesen. Früher ist Pat. immer gesund gewesen, seit drei Monaten fühlt er sich kränklich. Seit vier Tagen besteht Husten mit blutigem Auswurf. Keine Nachtschweisse. Aufnahme am 27. VIII. 1905.

Status: Ziemlich kräftig gebauter Mann in ausreichendem Ernährungszustande. Über der rechten Lunge leichte Spitzendämpfung, Exspirium bronchial, nach Husten wenig Rasseln, sonst kein abnormer Befund. Im Auswurf Tuberkelbazillen vorhanden.

In den ersten Tagen hier mässig starke Hämoptöe mit Fieberanstieg bis $38^{\circ}$, später ist Pat. immer fieberfrei geblieben.

Nach 10 Tagen Beginn der Serumbehandlung. Pat. erhielt 37 Eingiessungen, à $10 \mathrm{ccm}$.

$$
\begin{aligned}
& \text { 6. September bis 6. Oktober Einlauf } 1-29 \text {, } \\
& \text { 17. Oktober }, 25 .
\end{aligned}
$$

Die Temperatur in der Zeit der Behandlung wie in der Pause schwankte gewöhnlich zwischen $36^{\circ}$ und $36,5^{\circ}$. Nachteilige Folgen sind nicht entstanden.

Pat. hat sich gut erholt. Bei dem Verlassen der Anstalt am 26. X. 1905 war perkutorisch derselbe Befund wie zu Anfang. Die Rasselgeräusche waren verschwunden; es bestand noch bronchiales Exspirium. Sein Gewicht war in den zwei Monaten von 100 auf 112 Pfund gestiegen.

Fall 13. Dietrich H., Weinküfer, 24 Jahre.

Hereditäre Belastung nicht nachgewiesen. Seit $1^{1 / 2}$ Jahren ist Pat. heiser, seit $1 \mathrm{Jahr}$ besteht Husten mit Auswurf. Aufnahme 30. VIII. 1905.

Status: Kräftig gebauter junger Mann mit mässigem Fettpolster. Es besteht Dämpfung über der linken Lungenspitze bis hinab zur dritten Rippe und zar Mitte der Skapula, daselbst viele, zun Teil klingende Rasselgeräusche.

Pat. spricht absolut heiser, zuweilen vollständig stimmlos. Stimmbänder sind gerötet und geschwollen. An den hinteren Enden der Stimmbänder Ulzerationen. Schwellung der Hinterwand, Verdacht auf Ulcus.

Pat. hat ziemlich viel Auswurf mit Tuberkelbazillen. Nach vier Wochen ist der Kehlkopf einmal galvanokaustisch behandelt.

Pat. ist stets fieberfrei gewesen, hat innerhalb $2^{1}{ }_{2}$ Monaten 50 Serumeinläufe à $10 \mathrm{ccm}$ erhalten, musste einmal wegen Durchfall einige Tage mit der Behandlung aussetzen, hat sonst keinerlei Beschwerden durch die Kur gebabt. Pat. erholt sich gut, ist noch in Behandlung.

Statt der Spitze ist jetzt die ganze linke Seite vorn gedämpft, mittelblasige Rasselgeräusche sind bis zur vierten Rippe nachweisbar. Hinten hat die Dämpfung sich nicht vergrössert, hat mehr an Intensität abgenommen, im Bereiche derselben besteht noch Katarrh, über der rechten Lunge ist keine Dämpfung, doch sind in der Spitze einzelne kleinblasige Rasselgexäusche hörbar. 
Der Kehlkopfbefund ist folgender: Die Aryknorpel leicht geschwollen, obwohl der obere Teil der Hinterwand vollständig vernarbt erscheint. Auf der unteren Hälfte der Hinterwand ragen noch zwei kleine Zacken hervor. Die ziemlich stark geschwollenen Taschenbänder legen sich wie Polster auf die anscheinend gesunden Stimmbänder und bedingen die stark heisere Sprache. Die Taschenbänder tragen auf der Oberfläche flache Cilcera.

Pat. hat sich jetzt der Behandlung mit Serumeinläufen wieder unterzogen. Die Sputummenge hat abgenommen, Tuberkelbazillen sind spärlich vorhanden. Das Gewicht ist in $3^{1} 2$ Monaten von 131 auf 161 Pfund gestiegen.

Fall 14. Albert B., Schüler, 15 Jahre.

Eltern und Geschwister gesund. Pat. hat vor zwei Jahren Knochenhautentzündung am linken Arm gehabt, vorigen Winter Bluthusten, desgl. zweimal in diesem Sommer. Seit einigen Wochen Husten mit sehr wenig Auswurf. Pat. leidet stark an Nachtschweissen. Aufnahme 3. IX. 1905.

Status: Kräftig gebauter junger Mann in gutem Ernährungszustande. Der objektive Lungenbefund sehr gering, es ist keine Dämpfung nachzuweisen, doch hört man über der linken Lungenspitze klingendes Rasseln.

Sputum sehr spärlich, Tuberkelbazillen darin bei mehrmaliger Untersuchung nicht nachzuweisen.

Pat. bekam hier nach der ersten Woche eine drei Tage lang anhaltende, mässig starke Hämoptöe mit Temperaturerhöhung auf $38,8^{\circ}$, sonst ist Pat. immer fieberfrei gewesen.

Am 21. IX. Beginn der Serumbehandlung mit Darmeingiessungen à $10 \mathrm{ccm}$.

$$
\begin{aligned}
& \text { 21. IX. bis 7. X. Einlauf } 1-13 \text {, } \\
& \text { 17. X. }, 21 . X ., 14-18 .
\end{aligned}
$$

Anfang Oktober war die Spitzenaffektion auch durch leichte Dämpfung nachweisbar, auskultatorisch hörte man noch ziemlich viel Rasseln. Bei dem Verlassen der Anstalt am 22. X. war der Katarrh etwas gebessert, man hörto noch einzelne Rasselgeräusche. Pat. hat sich gut erholt, das Körpergewicht ist von 109 auf $117^{1 / 2}$ Pfund gestiegen.

Fall 15. Bruno G., Tischler, 26 Jahre.

Hereditäre Belastung nicht nachgewiesen. Pat. ist früher immer gesund gewesen, hat vor fünf Jahren gedient, hat seit ${ }^{3}{ }_{4} \mathrm{Jahr}$ Husten mit Auswurf, muss nachts stark schwitzen, hat in der letzten Zeit abgenommen. Aufnahme 22. VIII. 1905.

Es handelt sich um einen Pat. mit leichter Spitzenaffektion beiderseits, linke Spitze ist etwas mehr gedämpft als die rechte, links wenig Katarrh.

Sputum spärlich. Tuberkelbazillen vorhanden. Es bestehen starke Nachtschweisse.

Die Serumbehandlung bestand in Darmeinläufen (10), später auf seinen Wunsch in Injektionen (9). Der Lungenbefund blieb bis zu seiner Entlassung am 14. X. derselbe wie zu Anfang.

Die Nachtschweisse haben aufgehört. Der Husten war zu Anfang etwas häufiger, ohne dass der Auswarf reichlich war.

Pat. ist immer fieberfrei gewesen, hat weder durch Serumeinläufe noch durch Injektionen Temperatursteigerungen erfahren. Das Gewicht ist von 124 auf 132 Pfund gestiegen.

Leider musste Pat. wegen Unbotmässigkeit nach 7 wöchiger Behandlung aus der Anstalt entlassen werden. 
Fall 16. Heinrich A., Zimmermann, 34 Jahre.

Pat. hat seit zwei Jahren Schmerzen im Leibe, musste zweimal deswegen kurze Zeit die Arbeit aussetzen, hat regelmässigen Stuhlgang, kein Erbrechen, muss seit $1 / 2$ Jahr nachts stark schwitzen, klagt über Mattigkeit, ist seit $1 / 2 \mathrm{Jahr}$ heiser. Aufnahme 21. VII. 1905.

Status: Schmächtiger, grosser, abgemagerter Mann. Über der rechten Lungenspitze besteht ober- und unterhalb der Klavikula Dämpfung, daselbst vereinzelte kleinblasige Rasselgeräusche hörbar. Kehldeckel geschwollen, an der linken Innenfläche Narben eines abgeheilten Geschwüres. Linke aryepiglottische Falte stark geschwollen, an der Innenfläche ein tiefliegendes linsengrosses Ulcus. Taschenbänder leicht geschwollen und gerötet.

Sputum spärlich, Tuberkelbazillen massenhaft vorhanden. Pat. fiebert meist zwischen 36,5 und $37,9^{\circ} \mathrm{C}$. Durch 23 Serumeinläufe ist das Fieber nicht beeinflusst. Die Leibschmerzen, wofür der objektive Befund keine Aufklärung gab, liessen mit der Zeit etwas nach, doch blieben die Symptome über den Atmungsorganen dieselben.

Anfangs nahm Pat. um 6 Pfund $\mathrm{zu}$, nahm aber wieder ab und verschlechterte sich merklich, Nach zweimonatlichem Aufenthalte in der Anstalt musste Pat. auf seinen Wunsch hin entlassen werden.

Wie wir hören, ist Pat. inzwischen gestorben. Sektion ist nicht ausgeführt.

\section{Driisentuberkulose.}

Fall 17. Friedrich J., Tischler, 23 Jahre.

Pat. ist ein kräftig gebauter, gut genährter Mann mit auffällig breitem Halse. Am Halse, besonders rechterseits sind mehrfach Drüsenexstirpationen vorgenommen, es sind dort 13 zum Teil recht grosse Narben sichtbar. Trotz der vielen chirurgischen Eingriffe ist es nicht gelungen, die Drüsen zu beseitigen. Der Hals setzt über der Klavikula breit an. Man fühlt am rechten Kieferwinkel starke Drüsenpakete, desgleichen am rechten Sternokleidomastoideus ein $\mathbf{3} \mathrm{cm}$ breites, hartes Drüsenpaket. Am Nacken sind zahlreiche kleinere Drüsen fühlbar, ferner an Stelle der Parotis rechts ein verhärteter, nicht scharf abgegrenzter Drüsenballen, so dass die rechte Backe bedeutend dicker erscheint als die linke. Die zahlreichen Narben sind hochrot und verursachen zum Teil straffe Kontrakturen. An vier Stellen haben sich Fisteln gebildet, aus welchen sich Sekret entleert.

Über den Lungen ist eine manifeste Phthise nicht nachweisbar, es besteht jedoch Verdacht auf einen beginnenden tuberkulösen Prozess in den Spitzen. Husten fehlt.

Pat. fieberfrei, begann die Seruminjektionskur am 29. VII. und erhielt bis 9. Oktober 20 Einspritzungen à $5 \mathrm{ccm}$ und 14 Darmeinläufe à $10 \mathrm{ccm}$. Sein Befinden war stets gut. Temperatursteigerungen sind nicht vorgekommen. 10. X. Entlassung.

Der Hals ist im ganzen schmaler, die Drüsenpakete sind nicht mehr vorhanden, die Haut im Bereiche der Narben zeigt, abgesehen von den Kontrakturen, normale Beschaffenheit, man fühlt unter ihr noch vereinzelte kleinere Drüsen. Die Fisteln haben sich geschlossen und sind vernarbt.

Obgleich Pat. auf der chirurgischen Abteilung seit Mai 1904 in Behandlung war und demnach die Verpflegung wïhrend der Serumbehandlung die gleiche war wie vorher, ist das Körpergewicht in den letzten $2^{1}$. Monaten von 135 auf 148 Pfund gestiegen. 
Pat. verlässt die Anstalt arbeitsfähig, ohne Beschwerden am Halse. Eine Nachuntersuchung nach sechs Wochen ergab dasselbe günstige Resultat.

Fall 18. Auguste N., Putzmacherin, 23 Jahre.

Erbliche Belastung nachgewiesen. Vor drei Jahren Anschwellung der rechtsseitigen Halslymphdrüsen, darauf operative Entfernung derselben.

Im April dieses Jabres Anschwellung der Parotisdrüse mit Infiltration der Umgebung. Am 8. V. Exzision verkäster Drüsen mit zähen Verwachsungen unter dem rechten Kieferwinkel. Auf der Wange zwei Inzisionen. Die Wunden sind mit breiter Narbe verheilt, es bestehen aber noch zwei Fistelöffnungen, aus welchen klares Sekret ausfliesst. Die rechte Wange ist stark geschwollen, im Umkreis der Narben in der Parotisgegend besteht starke Infiltration der Haut, man fühlt unter ihr eine runde, etwa $5 \mathrm{~cm}$ im Durchmesser haltende, $2 \mathrm{~cm}$ hohe, flache, konsistente Gescbwulst.

Über den Lungen besteht leichte Spitzendämpfung, rechts mit ganz geringen katarrhalischen Erscheinungen, über den unteren Lungenpartien beider Lungen hört man vereinzeltes kleinblasiges Rasseln.

Am 29. VII. Beginn der Serumbehandlung.

\begin{tabular}{|c|c|c|c|c|}
\hline 29. Juli & bis 16. August & Injektion & $1-10$ & 5 \\
\hline . & 18. September & & $11-20$ & \\
\hline tember & 2. Oktober & Einlauf & $1-9$ & \\
\hline 17. Oktober & 10. November & Injektion & $21-30$ & \\
\hline
\end{tabular}

Pat. war stets fieberfrei, hat niemals auch nur kleine Temperatursteigerungen gehabt. Entlassung am 13. XI. 1905.

Die Schwellung der Wange hat bedeutend abgenommen, es besteht jedoch im Vergleich zur linken noch etwas Verdickung. Die Infiltration ist vollständig geschwunden, die Haut hat ihre normale Beschaffenheit und Farbe. Die Geschwulst ist weich und auf die Grösse einer Mandel verkleinert. Die Fisteln haben sich geschlossen.

Die Lungen sind bedeutend gebessert, der Katarrh über den unteren Lungenpartien ist beseitigt, über der rechten Spitze besteht noch schwache Dämpfung und man hört daselbst noch ganz vereinzeltes leises Knacken. Obgleich Pat. schon vor der Behandlung seit Anfang April in der Krankenanstalt verpflegt war, ist ihr Gewicht während der Serumbehandlung von 126 auf 134 Pfund gestiegen.

Nachuntersuchung nach sechs Wochen ergibt völlige Heilung.

Fall 19. Sophie B., Köchin, 25 Jahre.

Pat. kam am 22. Mai in die Krankenanstalt wegen starker Anschwelluug der Halsdrüsen. In der letzten Zeit Abmagerung.

Status: Blass aussehendes, mässig genährtes junges Mädchen.

Lungen ohne pathologischen Befund. Über beiden Schlüsselbeinen befinden sich grosse Drüsenpakete, welche die Basis des Halses verbreitern, oberbalb des sternalen Teiles des linken Schlüsseibeines ist eine halbhühnereigrosse Prominenz durch Drüsenschwellung entstanden. Axillardrüsen fühlbar.

Pat. fiebert mit grossen Remissionen (s. Kurve). Beginn der Serumbehandlung am 29. VII., das Fieber war gegen Ende Juli auf $37,4-37,6^{\circ}$ abgefallen.

In dem Befinden der Pat. trat mit Beginn der Serumbehandlung eine auffallende Änderung ein, sie vertrug die Einspritzungen sehr gut und erholte sich sichtlich. Temperatursteigerungen sind nicht mehr vorgekommen. 
Die Zeiteinteilung der Behandlung war folgende:
29. Juli
bis 16. August
Injektion
28. August
18. September
inlauf
$1-10$ à $5 \mathrm{ccm}$
22. September
3. Oktober
Einlauf
$\begin{array}{rrr}11-20 & \text { à } & 5 \\ 1-10 & \text { à } & 10\end{array}$

Entlassung am 10. X. 1905.

Der Drüsenbuckel ist verschwunden, Hals vollständig geebnet. Oberhalb des linken Schlüsselbeins ist eine kleinwalnussgrosse, oberhalb des rechten eine haselnussgrosse Drüse fühlbar.

Pat. hat ein frisches Aussehen. Ihr Gewicht, das in der Anstalt um 3 Pfund abgenommen hatte, hat seit der Serumbehandlung um 28 Pfund zugenommen, s. Gewichtskurve.

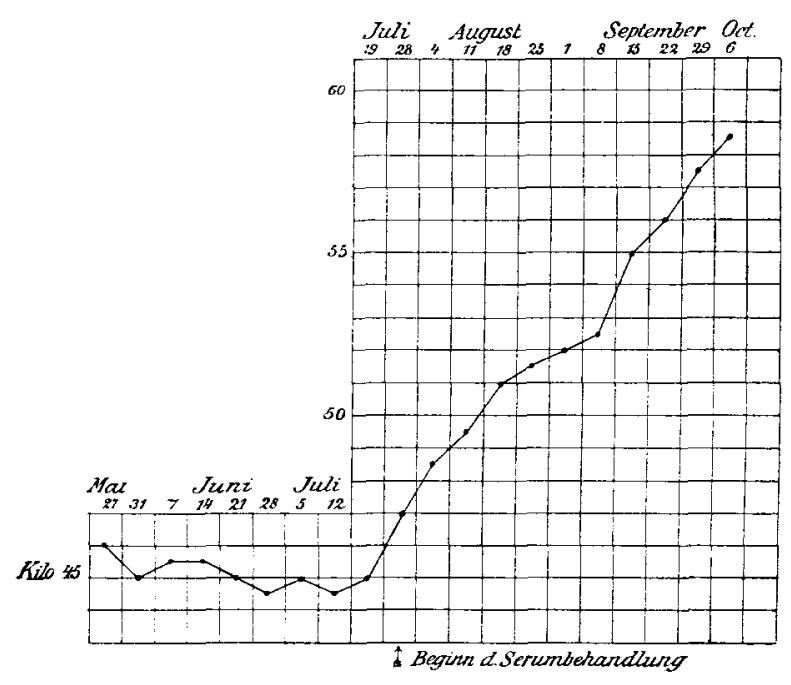

Fall 20. Frieda P., Dienstmagd, 23 Jahre.

Pat. stammt aus tuberkulöser Familie, hat mit 13 Jahren Lungenkatarrh gehabt (ist ${ }^{3}+\mathrm{Jahr}$ krank gewesen). Im Februar vorigen Jahres Entbindung mit nachfolgender Mastitis. Seit $1 / 4 \mathrm{Jahr}$ sind die Halsdrüsen angeschwollen. Am 18. VII. operative Entfernung eines Teiles der Halsdrüsen.

Am 11. VIII. Beginn der Serumeinspritzungen. Es bestanden damals an der linken Balsseite eine walnussgrosse und fünf kleinere, an der rechten drei mandelgrosse Drüsen. Die grossen Drüsen bildeten an der Halsoberfläche stark prominierende Buckel.

Über der linken Lunge war leichte Spitzendämpfung nachweisbar, auf der Höhe des Inspiriums börte man vereinzeltes Knacken.

Pat. hat bis 2. Dezember 30 Finspritzungen, à $5 \mathrm{ccm}$, erhalten. Die Drüsen sind unter der Haut verschieblich, doch hat ihre Grösse nur wenig abgenommen. Der Lungenbefund ist derselbe geblieben.

Abgesehen davon, dass die Injektionsstelle einige Male geschwollen und etwas schmerzhaft war, hat Pat. nachteilige Folgen von der Serumbehandiung nicht gehabt.

$\mathrm{Zu}$ bemerken ist noch, dass $\mathrm{P}$. captiva war und nicht an der Freiluftbehandlung teilnehmen konnte. 


\section{Hanttuberkulose.}

Fall 21. Frau R., 35 Jahre.

Beginn der Erkrankung vor $1^{1} / 2$ Jahren am rechten Oberarm und Dorsalfläche der rechten Hand. Nach Auskratzung der hier entstandenen Hautgeschwüre keine Ausbeilung an der Hand, während der Oberarm nach Inzision binnen zwei Monaten beilte.

Anfang März dieses Jahres entstanden am rechten Unterarm über den unteren Epikondylen des Radius und der Ulna zwei oberflächliche Geschwüre, aus welchen sich viel Eiter entleerte. Im Juni entstand ein Geschwür am oberen Teil des Unterarmes. Die Geschwüre zeigten keine Tendenz zur Heilung, sondern es ent. standen nun an der ganzen Oberfläche des Unterarmes ein Geschwür neben dem andern, so dass nur wenig normale Haut erhalten blieb. Seitdem bestand die Behandlung in Verbinden mit Borsalbe und Wundwatte.

Aufnahme in die Anstalt Mitte November.

Status: Der Unterarm ist in toto geschwollen, hauptsächlich unterhalb des Ellenbogengelenkes. Die Haut ist hier stark gespannt und infiltriert. Auf der granzen Oberfläche des Unterarmes bestehen eine grosse Reihe von Geschwüren, das Handgelenk und der Handrücken sind ganz von Geschwüren bedeckt. In der Mitte des Unterarmes stehen die Geschwüre isolierter, doch sind einige durch Kanäle unter der Haut verbunden. Die Ränder der Geschwüre sind stark gewulstet.

Linkerseits besteht Schwellung und Fluktuation über dem Erbsenbein. Eine Röntgenaufnahme zeigte deutliche Veränderung des Erbsenbeines, wohingegen Ulna und Radius des rechten Armes intakt erschienen.

Pat. hat vom 23. XI. bis 17. XII. 10 Einspritzungen, à $10 \mathrm{ccm}$, erhalten; es sind viermal Temperatursteigerungen auf 37,5 , einmal auf $37,9^{\circ}$ vorgekommen, sonst blieb Pat. fieberfrei. Lokale Reaktionen fehlten so gut wie ganz. Der Arm wurde täglich mit steriler Gaze verbunden.

19. XII. Der Arm ist abgeschwoilen, die Geschwüre haben sich gereinigt und sind bedeutend flacher geworden. Die Haut unterhalb des Ellenbogens ist noch straff, dagegen lässt sie sich am übrigen Unterarm in Falten abheben. Die Infiltration in der Umgebung der Geschwüre ist geringer, die Eiterabsonderung ist bedeutend zurückgegangen. Das tuberkulös erkrankte Erbsenbein des linken Handgelenkes wurde am 19. XII. exstirpiert.

Was die Lunge anbetrifft, so hatte Pat. im vorigen Winter Husten mit viel Auswurf, im Sommer verspürte sie Besserung, im Herbste wieder Verschlechterung.

Über der linken Lungenspitze bestand bei ihrer Aufnahme leichte Dämpfung. Auskultatorisch waren einzelne knackende Geräusche hörbar. Pat. hatte mässigen Husten mit spärlichem Auswurf. Tuberkelbazillen sind bis jetzt nicht im Auswurf nachgewiesen.

19. XIl. Seit acht Tagen braucht Pat. nicht mehr zu husten. Der Lungenbefund ist derselbe wie zu Anfang der Behandlung.

Pat. hat um zwei Pfund zugenommen, ist noch in Behandlung.

\section{Knochentuberkulose.}

Fall 22. Erna T., 16 Jahre.

Vater früher lungenkrank, mit Ko chs Tuberkulin behandelt. Pat. hat vor 2 Jahren Lungenentzïndung durchgemacht, seit $1 \frac{1 / 2}{2}$ Jahren besteht Lungenkatarrh mit Husten und Auswurf, welcher zeitweise sich besserte. 
Seit letztem Winter Schmerzanfälle im Rücken, anfangs nur eine Stunde dauernd und nach einigen Wochen sich wiederholend, in letzter Zeit jede Woche auftretend und ein bis zwei Tage und länger anhaltend. Aufnahme 25. VIII. 1905.

Status: Zart gebautes junges Mädchen mit fahler Gesichtsfarbe, Fettpolster stark geschwunden. Die Wirbelsăule zeigt im Lendenteile eine schwache Abweichung mit der Konvexität nach rechts. Der zweite Lendenwirbel ist druckempfindlich. Die photographische Platte nach einer Röntgenaufnahme zeigt den oberen Rand des zweiten Lendenwirbels als eine nicht ganz scharfe Linie im Gegensatz zu den anderen Wirbeln.

Über der rechten Lunge besteht starke Dämpfung der Fossa supraclavicul. und Fossa supraspinata, leichte Dämpfung etwas weiter abwärts. In der Spitze hört man Bronchialatmen mit spärlichen, weiter abwärts verschärftes Atmen mit zablreichen Rasselgeräuschen, in den unteren Lungenpartien verschärftes Vesikuläratmen. Die linke Lungenspitze ist gleichfalls bis zum Schlüsselbein und Schulterblattkamm gedämpft, über der ganzen linken Lunge hört man mittel- und kleinblasiges Rasseln.

Herztätigkeit sehr beschleunigt. Sputum im allgemeinen spärlich, Tuberkelbazillen in mässiger Menge vorhanden.

Es wurde die Serumbehandlung nach drei Tagen der Beobachtung begonnen bei der 'Temperatur von $38,6^{\circ} \mathrm{C}$. Wie aus der Kurve ersichtlich, traten bis znm 20. IX. zwei schwere und zwei leichte Schmerzanfälle auf. Pat. wusste bei den schweren sich vor Schmerzen im Bette kaum zu halten. Morphium-Einspritzungen konnten den Schmerz wohl etwas lindern, jedoch nicht beseitigen. Nach diesen Anfällen ist später keiner wieder vorgekommen, obgleich Pat. den ganzen Tag ausser Bett, vorwiegend auf dem Liegestuhl zubrachte. Da die Anfälle zu Hause jede Woche auch bei vollständiger Ruhelage sich einstellten, so lag es nahe, das Fortbleiben der Anfälle als Folge der Wirkung des Serums anzusehen. Die ersten Injektionen vertrug Pat. leidlich, ohne lokale Reaktion, später wurde sie jedoch gegen die Einspritzungen immer empfindlicher und es folgten der Injektion bemerkenswerte Temperaturen. Der Oberschenkel war in solchen Fällen stark geschwollen and gerötet und bei Berührung sehr schmerzhaft. Wir sahen uns daher schliesslich genötigt, die Injektionen aufzugeben. Pat. hatte 13 Injektionen und 10 Darmeingiessungen erhalten. Das Fieber ist nur zeitweise beseitigt gewesen, das Körpergewicht war von 81 auf 90 Pfund gestiegen.

Nach dem Gesagten litt Pat. an Lungentuberkulose und Karies der Wirbelsäule. Die erstere ist während der Behandlung unverändert geblieben, die Besserung des Allgemeinbefindens ist wohl der energisch durchgeführten Freiluftbehandlung zuzuschreiben, dagegen sind wir geneigt, das Ausbleiben der durch dio Karies bedingten Schmerzanfälle auf die Seruminjektionen zurückzůïihren.

Fall 23. Karl H., Schuhmacher, 22 Jahre.

Pat. hat seit mehreren Jahren Schmerzen in der Wirbelsäule, hauptsächlich beim Bücken, seit etwa zwei Wochen Schwellung in der rechten Hand. Aufnahme auf der chirurgischen Abteilung am 25. IV. 1905. Am 12. V. musste der rechte vierte Mittelhandknochen wegen Tuberkulose entfernt werden. Die Wunde an der Dorsalfäche der Hand heilte, doch bildeten sich nach vier Wochen Fisteln. Am 21. VI. wurde Pat. wegen Schmerzen im Rücken auf ein Gipsbett gelagert, bei ruhiger Lage hatte er keine Schmerzen, dagegen sehr starke in dem unteren Teil der Brustwirbelsäule nach kurzem Aufrichten.

Pat. fiebert beständig, zeitweise zwischen $37,5^{\circ}$ und $38,5^{\circ}$, zeitweise $z$ wischen $37,0^{\circ}$ und $37,8^{\circ}$ bis 26 . VIr. 
Am 29. VII. Beginn der Serumbehandlung, die Zeiteinteilung war folgende:
27. Juli
bis 16. August
Injektion 1-10. ̀̀ $5 \mathrm{ccm}$
28. August
18. September
$11-20$ à 5 ,
20. September,
5. Oktober
"
S.-Einlauf 1-14 à 5 ,
17. Oktober
20. November Injektion $21-30$ à 5 .
4. November
$31(10 \mathrm{ccm})$
10. November bis 14. November 5 Einläufe à $20 \mathrm{ccm}$.

Mitte August konnte Pat. ohne Schmerzen das Bett verlassen, er gewöhnte sich daran, den ganzen Tag ausser Bett zu sein. Anfang September machten ihm Spaziergänge keine Beschwerden mehr, auch konnte er sich leidlich bücken. Mit der Freiheit seiner Bewegungen machte seine Erholung gute Fortschritte, sein Körpergewicht stieg in den ersten zwei Monaten (August und September) von 113 Pfund auf 129 Pfund.

Es entstanden an verschiedenen Stellen des Körpers kalte Abszesse, so links neben dem früher empfindlichen unteren Teil der Brustwirbelsäule (Anfang August), später am distalen Ende der rechten Ulna. Da letztere dem Pat. Beschwerden machte, sahen wir uns zu einem chirurgischen Eingriffe genötigt. Nach Inzision entleerte sich reichlich Eiter, in der Tiefe fühlte man den erkrankten rauhen Knochen. Die Wunde ist bis jetzt, Ende Dezember, noch nicht verheilt. Im Oktober wurde der Abszess neben der Wirbelsäule punktiert und inzidiert. Der Eiter hat sich an jener Stelle wieder angesammelt, so dass jetzt neben der Wirbelsäule eine enteneigrosse, fluktuierende Geschwulst besteht.

Seit November ist eine deutliche Verschlechterung auch in dem Befinden des Pat. eingetreten. Das Gewicht hat jetzt wieder um 9 Pfund abgenommen.

Pat. verspürte am 24. XI. Druckempfindlichkeit am lateralen Epikondylus des linken Femur, zugleich stieg die Temperatur bis $38,2^{\circ}$. Objektiv war eine geringe Schwellung der Aussenseite des linken Knies zu konstatieren. Es war demnach wieder ein frischer tuberkulöser Herd entstanden, der das Fieber verursachte. Weitere Erscheinungen am Knie folgten nicht nach.

Am 20. XII. klagte Pat. über Schmerzen im Nacken. Die rechtè Seite derselben ist etwas dicker als die linke, vermutet wird auch dort die Entstehung eines kalten Abszesses.

Da Anfang Dezember das Fieber fortdauerte (s. Kurve), wurde am 4. XII. eine Injektion von $10 \mathrm{ccm}$ Serum gemacht, nach welcher das Fieber auf $39,0^{\circ}$ anstieg. An der Injektionsstelle selbst war Rötung und Schwellung eine unliebsame Folge der Einspritzung. Das Fieber ging dann auf die frühere Höhe zurück. Nimmt man an, dass das Fieber bei Knochentuberkulose, welche als eine Reininfektion zu betrachten ist, zum Teil durch die Toxine der Tuberkelbazillen hervorgerufen werden kann, so müsste durch Zufuhr von Antitoxinen das Fieber beseitigt werden können. Um eine lokale Reaktion, die Quelle eines neuen Fiebers, zu vermeiden, wurden jetzt Linläufe von $20 \mathrm{ccm}$ Serum vom 10.-14. XII. gemacht. Tatsächlich fand eine zeitweise Entfieberung statt (s. Kurve). Weitere Versuche werden in folgender Zeit noch gemacht werden. Bis jetzt ist es vielleicht gelungen, das Fieber bei einer Reininfektion zu beeinflussen, nicht aber, den Krankheitsprozess als solchen aufzuhalten.

Wie in dem vorigen Falle wurde durch die Serumbehandlung der Prozess in der Wirbelsäule auffallig beeinflusst, da der Kranke kurze Zeit nach Beginn der Behandlung sich frei bewegen konnte. Leider ist die Wirkung keine dauerhafte gewesen, denn spontan sind neue Knochenprozesse entstanden. 


\section{Blasentuberkulose.}

Fall 24. Friedrich G., Schlächter, 27 Jahre.

Pat. hatte $1901 \mathrm{zum}$ erstenmal Blut im Urin, seitdem noch fünf- bis sechsmal, zuletzt vor vier Wochen. Schmerzen haben nie bestanden. Pat. hat bisher gearbeitet. Aufnahme 13. X. 1905.

Kräftig gebauter, gut genährter junger Mann. Brustorgane ohne Befund. Pat. muss tagsüber vier- bis fünfmal Urin lassen, in Einzelmengen von etwa $500 \mathrm{ccm}$. Tuberkelbazillen im Urin sind bakteriologisch und durch Tierversuch nachgewiesen.

Die Zystoskopie ergab folgendes:

Schleimhaut der Blase im allgemeinen frei, hellgelb mit einzelnen roten Gefässen. Am Blasenboden Trigonum schmutzig dunkelrot, am linken Ureteralwulst eine $2 \mathrm{~cm}$ lange und ${ }^{x_{2}} \mathrm{~cm}$ breite, strichförmige Infiltration, neben derselben ein haselnussgross erscheinender, graurötlicher Tumor, medianwärts ein linsengrosses, rotes, infiltriertes Knötchen.

Die Behandlung mit Seruminjektionen begann am 20. X. 1905. Pat. erhielt mit Intervallen von zwei bis höchstens vier Tagen bis zum 6. XII. in einer Tour 20 Einspritzungen, welche er obne Temperatursteigerungen gut vertrug. Einmal stieg die Temperatur an einem serumfreien Tage auf $37,5^{\circ} \mathrm{C}$. Lokale Reaktionen siud bei $\mathrm{jhm}$ sehr selten gewesen.

1. XI. starke Blasenblutung, seitdem Urin meist klar, stets frei von Blut.

15. XI. Zystoskopie: Die ganze Schleimhaut des Blasenbodens schmutzig rot verfärbt, teilweise mit eitrigen Belägen bedeckt. Tumor nicht mehr nachzuweisen. Die Infiltration auf dem Ureteralwulst erscheint als blaugrauer Fleck, das Knötchen besteht noch.

8. XII. Zystoskopie: An Stelle des früheren Granulationstumors befindet sich eine 1 Markstück grosse graue narbige Stelle, an deren Peripherie noch zwei kleine rote Knötchen sichtbar sind. Aus der linken Ureteralmündung entleert sich klarer Urin unter rhythmischen Kontraktionen. Die Ureteralmündung erscheint etwas erweitert, trichterförmig, leicht gerötet, unter derselben ist ein kleiner roter Punkt sichtbar. Die Blase in toto ist frei von Katarrb, Schleimhaut hell, Gefässe gut sichtbar. Die Kapazität beträgt $750 \mathrm{ccm}$.

Pat. sieht gesund aus, hat 8 Pfund zugenommen, ist frei von Beschwerden.

Seit dem 6. XII. wird mit den Einspritzungen eine dreiwöchige Pause gemacht.

Die Prognose auf volle Ausheilung ist günstig.

Fall 25. Dietrich Z., Maschinist, 31 Jahre.

Seit $2^{1 / 2}$ Monaten fast immer Blut im Urin. Pat. muss sehr häufig Wasser Iassen, hat in den letzten drei Monaten 20 Pfund an Gewicht verloren. Pat. ist wegen Blasenkatarrh mit Spülungen behandelt.

Status: Kräftig gebauter, breitschulteriger Mann in leidlichem Ernährungszustande. Brustorgane ohne pathologischen Befund.

Pat. klagt über Druckempfindung links unterhalb des Nabels, muss häufig urinieren, kann zurzeit nur $60 \mathrm{ccm}$ Urin halten. Urin sehr trübe, mit Blut vermischt. Reichliches Sediment, in demselben Eiterkörperchen, keine Zylinder. An Bakterien fanden sich zahlreiche säurefeste Stäbchen zu Nestern angeordnet (Tuberkelbazillen). Der Tierversuch bestätigte die Diagnose Tuberkulose.

Der Urin enthielt Albumen $1 / 4^{0}, 00$ nach Esbach. Bei der Zystoskopie sab man die Schleimhaut der ganzen Blase dunkelrot, sammetartig, ohne Gefässzeichnung. Am linken Ureteralwulst ein bohnengrosses, kraterförmiges Geschwür, aus dem Ureter entleerte sich mit kurzen Unterbrechungen blutiger Urin. Auf 
dem Blasenboden am linken Schenkel des Trigonum fünf kleine rote Knötchen, an dem rechten Schenkel in der Gegend der Ureteralöffnung ein grösseres und ein kleineres Knötchen.

Die Seruminjektionsbehandlung wurde eingeleitet mit Fortlassung jeder weiteren lokalen Behandlung.

Die Zeiteinteilung war folgende:

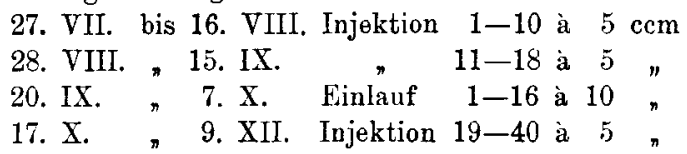

danach Einläufe à $20 \mathrm{ccm}$.

In der ersten Zeit hatte Pat. zuweilen noch stärkere Blutungen, besonders bei anstrengendem Stuhlgang usw. Im allgemeinen wurde der Urin klarer, die Druckempfindung links neben der Mitte der Linea alba liess nach. Pat. brauchte nicht mehr so häufig zu urinieren; er konnte nach drei Wochen der Behandlung $225 \mathrm{ccm}$ Urin halten.

21. VIII. Zystoskopie: Schleimhaut bedeutend blasser, im Fundus der Blase Gefässzeichnung teilweise zu erkennen. Geschwür an der linken Uretermündung verkleinert, aus dem Ureter entleert sich keine blutige Flüssigkeit.

Die Blasenreizung bei der Zystoskopie hatte unangenehme Folgen. Das Fassungsvermögen der Blase ging zurück von 225 auf $130 \mathrm{ccm}$, der Urin war in der folgenden Zeit sebr trübe, öfter blutig. Es wurde zuweilen klarer Urin mit grösseren Blutcoagulis und linsengrossen Eiterpfröpfen entleert. In diesen Pfröpfen fanden sich reichlich Tuberkelbazillen. Drei Wochen nach der Zystoskopie waren die Urineinzelmengen wieder auf $170 \mathrm{ccm}$ gestiegen. Seitảem wechselt häufig die Beschaffenheit des Urins, zuweilen ist er klarer, zuweilen trübe, doch nur sebr seiten blutig. Ein Fortschritt wie in der ersten Zeit der Behandlung ist seitdem nicht zu konstatieren. Der zystoskopische Befund hat sich eher verschlechtert.

Die Zystoskopie am 10. XII. konnte nur unter schwierigen Verhältnissen ausgeführt werden. Pat. hatte schon bei $100 \mathrm{ccm}$ Blasenfüllung starke Schmerzen. Die ganze Blase war diffus entzündet, die einzelnen Geschwüre und Knötchen waren nicht deutlich za sehen.

Der Eiweissgehalt des Urins hatte nicht abgenommen. Was das übrige Befinden des Pat. anlangt, so hat er, abgesehen von einigen Einspritzungen, nach welchen das Bein oder der Arm unter Fieber anschwollen, die Kur gut vertragen; sein Körpergewicht ist von 148 auf 177 Pfund bei strenger Liegekur in freier Luft gestiegen.

Am 4. I. 1906 morgens bekam Pat. starke Atemnot, das Herz versagte vollständig, auch durch alle Reizmittel war ein besserer Puls nicht zu erzielen. Die Atemnot wurde immer grösser, fast den ganzen Tag war der Puls kaum zu fühlen, abends trat der Tod ein.

Die Sektion ergab als alten Tuberkuloseherd eine verkäste Bronchialdrüse, von welcher wahrscheinlich eine Fortschleppung der Krankheit in die linke Niere stattgefunden hat. Diese war vollständig tuberkulös entartet, der Ureter stark verdickt. Die Blase zeigte ein dem zystoskopischen Befunde entsprechendes Bild von frischer Entzündung neben einzelnen abgeheilten Geschwüren. Die direkte Todesursache resultierte aus der Schlaffheit und Dilatation des rechten Herzens mit ausgedehnter Thrombusbildung in demselben. Von diesem aus waren einzelne Thrombusstiickchen in einzelne grössere Äste der Art. pulmonalis geraten. 
Werfen wir nun einen kurzen Rückblick.

Wir haben mit dieser Serumbehandlung eine wesentlich andere kennen gelernt, als sie bei anderen Infektionskrankheiten, wie bei der Diphtherie, ausgeübt wird. Die lange fortgesetzten Einspritzungen sind ja durch die Art der Krankheit, gegen welche sie wirksam sein sollen, bedingt. Es kommt darauf an, immer und immer wieder die von den Tuberkelbazillen erzeugten Gifte zu paralysieren, um so dem Körper zu Hilfe zu kommen und ihn in den Stand zu setzen, den Kampf mit gewissermassen nur ungiftigen Krankheitserregern $\mathbf{z u}$ übernehmen.

Die Serumeinspritzungen wurden im allgemeinen gut vertragen, es folgten nur selten Temperatursteigerungen von einigen Zehntel Grad, welche ausschliesslich auf die Injektion zu schreiben waren. Einige Male ist allerdings ein Fieber mit einem Anstiege bis um $2^{\circ} \mathrm{C}$ eingetreten, so zweimal, nachdem die Injektionen an dem Unterschenkel und dem Oberarm gemacht waren, Stellen, welche sich für voluminöse Einspritzungen nicht eignen. Sodann beobachteten wir öfters eine schmerzhafte Schwellung und Rötung des Oberschenkels, wenn beim Einstich ein Blutgefäss verletzt und ein Teil des Serums in eine Vene eingespritzt war. Abgesehen von Gefässverletzungen bewirkte zuweilen das Serum als solches eine lokale Reaktion. - Das Serum war nicht immer in gleicher Weise ohne Reiz, das Serum der meisten Pferde wurde gut vertragen, wohingegen das Serum eines Pferdes bei allen mit diesem behandelten Patienten schmerzhafte Rötung und Schwellung an der Injektionsstelle zur Folge hatte.

Weiter sind die Reaktionen nicht bei allen Kranken von gleicher Stärke. Einige Patienten haben von 30 Einspritzungen niemals wesentliche Unbequemlichkeiten gehabt, es waren dieses hauptsächlich die Kranken mit einem guten oder leidlichen Fettpolster, wohingegen abgemagerte leichter empfindlich gegen die Einspritzungen waren. In einem Falle sahen wir uns genötigt, von den Einspritzungen abzulassen. Bei einem anderen haben wir Lungenembolie, die gutartig vorüberging, beobachtet. Als ultimum refugium bleiben dann noch die nicht irritierenden Darmeingiessungen.

Die lokalen Reizerscheinungen schwinden in der Regel unter dem Eisbeutel in 1 bis 2 Tagen. Abszesse kommen bei genügend aseptischem Vorgehen nicht vor. Nach 452 Einspritzungen, welche wir gemacht haben, ist kein einziger Abszess gefolgt.

Wann sind die Injektionen indiziert? - Eine absolute Kontraindikation existiert nicht, auch bei Kranken mit Fieber über $39,0^{\circ}$ haben wir ohne Nachteil eingespritzt. Marmorek selbst gibt an, dass in Fällen von lange anhaltendem Fieber mehr die Darmein- 
giessungen angezeigt sind, bei Kranken in leidlichem Stadium mehr die Einspritzungen. Im allgemeinen zogen wir die subkutanen Einspritzungen den Darmeingiessungen vor, weil wir uns von der subkutanen Injektion eine energischere Wirkung versprachen als von den Darmeingiessungen. Zweifellos geht auch von dem Darm aus ein grosser Teil des Serums in die Säftemasse des Körpers über, doch lässt sich hier eine genauere Dosierung nicht verfolgen. Erfolge, soweit wir solche auf die Serumwirkung setzen dürfen, sahen wir nach beiden Applikationsarten.

Ein Moment möchten wir noch hervorheben, das in unserer Anstalt, wo beide Arten der Serumbehandlung geübt wurden, nicht unwesentlich war, nämlich die psychische Beeinflussung durch derartige Eingriffe. Die Kranken selbst waren geneigt, die Einspritzung als das besser Wirkende anzusehen; ein Kranker, der mit Darmeingiessungen behandelt war, bat direkt darum, mit Einspritzungen weiter behandelt $\mathrm{zu}$ werden. Es ist möglich, dass die Kranken den schmerzhaften Eingriff unbewusst für wirksamer halten.

In der letzten Zeit sind wir dem Rate Marmoreks gefolgt, den Körper einer dauernden Serumeinwirkung zu unterwerfen, indem in den Pausen zwischen den Injektionen täglich Darmeingiessungen gemacht werden. Um durch den Darm auch energischer wirken zu können, haben wir bei dem Patienten mit der Blasen- und Nierentuberkulose während der Injektionspause täglich 15 , später $20 \mathrm{ccm}$ Serum durch den Darm appliziert.

Was nun die Erfolge anbetrifft, so lässt sich schwer mit Sicherheit entscheiden, welchen Teil der Besserung das Serum, welchen Teil die Ruhe und frische Luft bewirkten. Als feststehend muss man ansehen, dass man bei der Tuberkulosebehandlung die frische Luft gar nicht entbehren kann. Ein lehrreiches Beispiel ist uns der Fall 4, ein Mädchen, das bisher auf dem Saale der medizinischen Abteilung gelegen hatte und zur Serumbehandlung in das Luftkurhaus verlegt wurde. Der Umschwung in dem Krankheitsverlaufe und der Fortschritt ihrer Besserung war so frappierend, dass wir geneigt sind, neben dem Serum auch der Freiluftbehandlung einen grassen Teil des Erfolges zuzurechnen. Mit diesen beiden Mitteln haben wir in diesem Falle einen ganz ausgezeichneten Erfolg erzielt, wie es auch die Gewichtskurve deutlich beweist.

Was nun die Phthisen im allgemeinen betrifft, so fehlt es uns klinisch allerdings an bestimmtem Beweismaterial für die günstige Serumbeeinflussung, denn wir haben auch ohne Serum gute Erfolge gehabt; nichtsdestoweniger haben wir in der Behandlung der Anfangsstadien von Phthise Anhaltspunkte, welche vielleicht auf eine Ein- 
wirkung des Serums hindeuten, so z. B. das Verschwinden der Tuberkelbazillen im Auswurf bei Fall 1. - Wie gesagt, mit positiver Sicherheit lässt sich nach den rein klinischen Erfahrungen allein nichts behaupten.

Wie aus den Krankengeschichten hervorgeht, haben wir Versuche an Kranken in allen Stadien gemacht. Der ungünstige Ausgang konnte in einigen Fällen nicht verhindert werden. Es handelt sich eben bei der Lungenphthise um Mischinfektionen, denen gegenüber das Antituberkuloseserum nicht das Gleichgewicht zu halten vermag. Auch in einem Falle von galoppierender Schwindsucht, wo wir eine reine tuberkulöse Infektion annehmen mussten (Fall 9), konnte der Kranke nicht gerettet werden.

Anders dagegen ist der Heilerfolg der Serumbehandlung bei chirurgischen Fällen. Obgleich man auch hier einwenden könnte, dass oft genug die Tuberkulose zur Ausheilung kommt, weist uns Verschiedenes auf den günstigen Einfluss des Serums hin, so das Verschwinden und Schrumpfen der Drüsen (Fall 17, 18, 19), das Fortbleiben der Schmerzanfälle (Fall 22), die Fieberlosigkeit bei der Knochentuberkulose während der Serumbehandlung (Fall 23), die prompte Abheilung der Schädigungen in der Blase (Fall 24). Alles das kann in der Beurteilung des Serums bestimmend wirken und zu neuen Versuchen auffordern, obgieich wir auch in einigen Fällen nach Besserungen wieder Verschlechterungen gesehen haben. Die anfänglich so günstigen Erfolge bei der Blasen- und Nierentuberkulose (Fall 25) und bei der allgemeinen Knochentuberkulose (Fall 23) haben leider nicht standgehalten, im Gegenteil die Prognose verschlechterte sich wieder. Ein abschliessendes Urteil wird erst durch eine weitere Reihe von Versuchen gewonnen werden können, vorläufig lässt sich vermuten, dass das Serum bei chirurgischer Tuberkulose einen bessernden resp. heilenden Einfluss auszuüben imstande ist.

$\mathrm{Zu}$ welchen Resultaten wir auf Grund der Blutuntersuchungen gekommen sind, wird unten gezeigt werden.

\section{Hämatologischer Teil.}

Im Verlaufe der Serumbehandlung sind von uns bei einer grösseren Anzahl der behandelten Patienten Blutuntersuchungen angestellt worden, wie sie Arneth in den letzten Jahren angegeben hat. Während bisher von den rerschiedensten Autoren die Leukozyten nur nach ihrer Zahl beriicksichtigt wurden, unterzieht Arneth jedes einzelne weisse Blutkörperchen einer genauen Betrachtung. Durch seine diffizilen Untersuchungen ist uns eine Möglichkeit gegeben, einen tieferen 
Einblick in das Blutzellenleben bei den verschiedensten Krankheiten zu machen, die im Blute vorgehenden Veränderungen bezüglich der Leukozyten mikroskopisch zu verfolgen und die Resultate der Untersuchungen durch sogenannte Blutbildtabellen zu veranschaulichen.

Die Methode der Untersuchung ist kurz folgende:

Bei der Durchmusterung der mit Fhrlichschem Triacid gefärbten Bluttrockenpräparate werden 100 neutrophile Leukozyten je nach ihrer Kernbeschaffenheit in Klassen registriert und die Zahlen der diesen Klassen angehörigen Leukozyten zu einer Blutbildtabelle zusammengestellt.

Der ersten Klasse gehören die neutrophilen Leukozyten mit einem Kern an; nach der Gestalt des Kernes richtet sich die Unterbringung der Leukozyten in drei Unterabteilungen. Zu der ersten zählen diejenigen mit einem völlig runden Kern als Myelozyten, zu der zweiten die mit einem weniggebuchteten, zur dritten diejenigen mit einem tiefgebuchteten Kerne, deren Einbuchtung die Hälfte der Breite des Kernstabes überschreitet. Die Unterabteilungen werden bezeichnet mit $\mathrm{M}, \mathrm{W}$ und $\mathrm{T}$.

Die zweite Klasse enthält die Leukozyten mit zwei Kernen; letztere können rund oder schlingenförmig sein. Es entstehen so drei Unterabteilungen für Leukozyten: mit zwei runden Kernen $(2 \mathrm{~K})$, mit zwei Schlingen ( 2 S), und mit einem Kern und einer Schlinge (1 K $1 \mathrm{~S})$.

Die dritte Klasse enthält Leukozyten mit drei Kernen, die vierte mit vier, die fünfte die mit fünf und mehr Kernen. Auch in diesen Klassen fordern die verschiedenen Kernformen und die Kombinationen von runden und schlingenförmigen Kernen entsprechende Unterabteilungen, so dass folgende Tabelle entsteht, welche etwa einem normalen Blutbilde entsprechen würde.

\begin{tabular}{|c|c|c|c|c|c|c|c|c|c|c|}
\hline Datum & $\mathbf{M}$ & W & $\mathrm{T}$ & $2 K$ & $2 \mathrm{~S}$ & $1 \mathrm{~K} 1 \mathrm{~S}$ & $3 \mathrm{~K}$ & $3 S$ & $2 \mathrm{~K} 1 \mathrm{~S}$ & $1 \mathrm{~K} 2 \mathrm{~S}$ \\
\hline \multirow[t]{3}{*}{ 13. XI. 05} & - & - & 5 & - & 20 & 16 & 7 & 4 & 20 & 11 \\
\hline & $4 \mathrm{~K}$ & $4 S$ & $3 \mathrm{~K}$ 1S & $1 \mathrm{~K} 3 \mathrm{~S}$ & $2 \mathrm{~K} 2 \mathrm{~S}$ & $5 \mathrm{~K}$ & $4 \mathrm{~K} 1 \mathrm{~S}$ & etc. & & \\
\hline & 5 & - & 9 & 1 & 1 & 1 & 一 & - & & \\
\hline
\end{tabular}

Da die Gesamtzahl aller Zellen immer 100 beträgt, so stellen die Zahlenangaben gleichzeitig auch die Prozentangaben dar. Die 
folgende Mustertabelle gibt das auf diese Weise erhaltene neutrophile Blutbild beim gesunden Erwachsenen wieder (Mittel aus 15 Einzeluntersuchungen nach Arneth).

\begin{tabular}{|c|c|c|c|c|c|c|c|c|c|c|}
\hline & $\mathbf{M}$ & $\mathrm{W}$ & $\mathrm{T}$ & $2 \mathrm{~K}$ & $2 \mathrm{~S}$ & $1 \mathrm{~K} 1 \mathrm{~S}$ & $3 \mathrm{~K}$ & $3 \mathrm{~S}$ & $2 \mathrm{~K}$ 1S & $1 \mathrm{~K} 2 \mathrm{~S}$ \\
\hline Mittel & - & 0,20 & 5,00 & 0,27 & 23,46 & 11,60 & 2,27 & 5,60 & 16,66 & 16,40 \\
\hline Summe & \multicolumn{3}{|c|}{$5,2^{\circ}: 0$} & \multicolumn{3}{|c|}{$35,33^{\circ} / 0$} & \multicolumn{4}{|c|}{$40,93^{\circ} \circ$} \\
\hline abgerundet & \multicolumn{3}{|c|}{$5^{\circ} 0$} & \multicolumn{3}{|c|}{$35^{0} 0$} & \multicolumn{4}{|c|}{$41^{\circ} 0$} \\
\hline
\end{tabular}

\begin{tabular}{|c|c|c|c|c|c|c|c|c|c|c|}
\hline & $4 \mathrm{~K}$ & $4 \mathrm{~S}$ & $3 \mathrm{~K} 1 \mathrm{~S}$ & $1 \mathrm{~K} 3 \mathrm{~S}$ & $2 \mathrm{~K} 2 \mathrm{~S}$ & $5 \mathrm{~K}$ & $4 \mathrm{~K} 1 \mathrm{~S}$ & $3 \mathrm{~K} 2 \mathrm{~S}$ & $4 \mathrm{~K} 2 \mathrm{~S}$ & $3 \mathrm{~K} 3 \mathrm{~S}$ \\
\hline Mittel & 3,80 & 0,07 & 6,40 & 1,60 & 4,73 & 1,00 & 0,40 & 0,40 & 0,07 & 0,07 \\
\hline Summe & \multicolumn{5}{|c|}{$16,6^{\prime \prime} 0$} & \multicolumn{5}{|c|}{$1,94^{\circ} \circ$} \\
\hline abgerundet & \multicolumn{5}{|c|}{$17^{\circ} \circ$} & \multicolumn{5}{|c|}{$2^{0}: 0$} \\
\hline
\end{tabular}

Arneth hat in seiner Monographie ${ }^{1}$ ) nachgewiesen, wie sehr bei den verschiedensten Krankheiten die neutrophilen Leukozyten beeinflusst werden. Aus der mehr oder weniger starken Verschiebung des Blutbildes nach links kann man ohne weiteres Rückschlüsse auf die Schwere der Krankheit machen. In derselben Weise, wie die Schädigungen durch die Beschaffenheit des Blutbildes sich klar demonstrieren lassen, müssen auch bei der Rekonvaleszenz, sei sie spontan oder durch therapeutische Massnahmen eingeleitet, die Besserungen sich deutlich im Blutbilde wiederspiegeln. In eklatanter Weise ist auch dieser Beweis bei Pneumonie und anderen Infektionskrankheiten von Arneth erbracht. Wenn also bei Vorgängen, die immer eine gewisse Zeit (Inkubationszeit, Rekonvaleszenz) beanspruchen, nachweisbare Veränderungen im Blute vorgehen, so müssen solche noch um so deutlicher hervortreten, wenn das Blut direkt affiziert oder der Körper mit grossen Mengen von Giften plötzlich überladen wird. Arneth berichtet über einen Fall von Salzsäurevergiftung, in deren Gefolge das Blutbild eine maximale Verschiebung nach links aufwies. In gleicher Weise bestätigen die Injektionsversuche an Tieren mit infektiösem Material die unmittelbare Beteiligung der neutrophilen Leukozyten an den pathologischen Verhältnissen. Die zahlreichen, von Arneth angestellten Blutuntersuchungen lassen es als unzweifel-

1) Die neutrophilen weissen Blutkörperchen bei Infektionskrankheiten. Gustav Fischer, Jena 1904. 
haft erscheinen, dass wir in den Leukozyten Träger von Abwehrmitteln gegen jegliche Art Schädigung des Körpers zu sehen haben. Nach ihm werden mit dem Aufbau der Leukozyten spezifische Antikörper gebildet, welche mit dem Zerfall der Zellen in das Blut übertreten, um sich mit den im Blute kreisenden belebten oder unbelebten Giften zu binden. Je älter die Leukozyten werden, je mehr Kernteilungen in ihnen vorgehen können, desto hochwertiger werden sie in der Produktion von Schutzstoffen.

Es ist eine feststehende Regel, dass bei irgendwelchen Schädigungen zuerst die gut ausgebildeten Leukozyten der vierten und fünften Klasse verbraucht werden, erst nachher verschwinden die jüngeren Massen aus der dritten Klasse, bis schliesslich sämtliche Leukozyten sich aus den beiden ersten Klassen mit einem und zwei Kernen rekrutieren. Mit dieser Tatsache ist uns aus dem Blutbilde neben dem Einblick in die Schwere der pathologischen Veränderung zugleich ein Anhaltspunkt in der Beurteilung der Widerstandskraft des Organismus gegeben, sobald wir ausser der Qualität der Leukozyten auch deren Quantität berücksichtigen. In dem höchsten Grade der Schwächung des Körpers besteht neben einer starken Alteration der Leukozyten eine meist bedeutende Hypoleukozytose. Demnach ist es nötig, um einen klaren Begriff über die Abwehrmittel des Körpers zu erhalten, sowohl Blutbildtabellen nach der Arnethschen Methode herzustellen als auch Zählungen sämtlicher Leukozyten vorzunehmen.

Leider ist es uns nicht möglich gewesen, die Zählungen auszuführen, doch haben wir durch Darstellungen des Blutbildes allein versucht, einen Einblick in das Zellleben des Blutes zu gewinnen und weitere Betrachtungen anzuschliessen.

Die Blutpräparate sind stets am Vormittage angefertigt. Die Zeit zwischen Seruminjektion und Blutentnahme betrug mindestens 24 Stunden. Fielen Injektion und Blutentnahme auf denselben Tag, so ging die Entnahme der Injektion roraus.

Die Blutpräparate wurden in absolutem Alkohol fixiert, dann gefärbt und aufbewahrt; wegen Zeitmangels konnten sie erst nach Abschluss des klinischen Teiles der Arbeit durchgemustert werden. Die Blutuntersuchungen sind demnach ganz unabhängig von den klinischen ausgeführt. - In jedem Falle zeigt die erste Tabelle das Blutbild vor der ersten Einspritzung. 
I. (cf. Fall 19). Sophie B.

\begin{tabular}{|c|c|c|c|c|c|c|c|c|c|c|c|c|c|c|c|c|}
\hline Datum & $M$ & $\mathrm{~W}$ & $\mathrm{~T}$ & $2 \mathrm{~K}$ & $2 s$ & $1 \mathrm{~K} \quad 1 \mathrm{~S}$ & $3 \mathrm{~K}$ & $3 s$ & $2 \mathrm{~K} 1 \mathrm{~S}$ & $1 \mathrm{~K} 2 \mathrm{~S}$ & $4 \mathrm{~K}$ & $4 \mathrm{~S}$ & $3 K \mathrm{~K}$ & $1 \mathrm{~K} 3 \mathrm{~S}$ & $2 \mathrm{~K} 2 \mathrm{~S}$ & $5 \mathrm{~K}$ \\
\hline 27. VII 05 & - & 1 & 30 & 3 & 18 & 23 & 5 & 2 & 9 & 6 & 3 & - & 一 & - & - & - \\
\hline 25. VIII. & - & 1 & 19 & 3 & 26 & 24 & 10 & - & 9 & 2 & 6 & - & - & - & - & - \\
\hline 7. IX. & - & - & 2 & 6 & 28 & 15 & 19 & 1 & 17 & 3 & 8 & - & 1 & - & - & - \\
\hline 15. IX. & - & - & 8 & 2 & 27 & 29 & 7 & - & 7 & 12 & 5 & - & - & - & 3 & - \\
\hline 10. X. & - & 1 & 2 & 5 & 26 & 10 & 16 & 1 & 23 & 4 & 5 & - & 5 & - & 2 & 一 \\
\hline 17. XI. & - & 1 & 1 & 3 & 18 & 21 & 20 & 2 & 12 & 7 & 11 & - & 2 & - & 1 & 1 \\
\hline 27. VII. & & 31 & & & 44 & & & & 22 & & & & 3 & & & 一 \\
\hline 25. VIII. & & 20 & & & 53 & & & & 21 & & & & 6 & & & 一 \\
\hline 7. IX. & & 2 & & & 49 & & & & 40 & & & & 9 & & & - \\
\hline 15. IX. & & 8 & & & 58 & & & & 26 & & & & 8 & & & 一 \\
\hline 10. X. & & 3 & & & 41 & & & & 44 & & & & 12 & & & - \\
\hline 17. XI. & & 2 & & & 42 & & & & 41 & & & & 14 & & & 1 \\
\hline & II. & (cf. & $\mathrm{Fal}$ & 17) & & riedri & & $\mathrm{J}$ & & & & & & & & \\
\hline Datum & $\mathbf{M}$ & W & $\mathrm{T}$ & $2 \mathrm{~K}$ & $2 \mathrm{~S}$ & $1 \mathrm{~K} \quad \mathrm{IS}$ & $3 \mathbf{K}$ & $3 \mathrm{~S}$ & $2 \mathrm{~K} 1 \mathrm{~S}$ & $1 \mathrm{~K} 2 \mathrm{~S}$ & $4 \mathrm{~K}$ & $4 \mathrm{~S}$ & $3 \mathrm{~K} 1 \mathrm{~S}$ & $1 \mathrm{~K} 3 \mathrm{~S}$ & $2 \mathrm{~K} 2 \mathrm{~S}$ & $5 \mathrm{~K}$ \\
\hline & & & & & & & & & & & & & & & & \\
\hline 27.VII.05 & 1 & 1 & 10 & 2 & 35 & 12 & 3 & 3 & 11 & 13 & 1 & - & 7 & - & 1 & - \\
\hline 25. VIII. & - & - & 8 & 1 & 24 & 17 & 11 & - & 15 & 9 & 11 & - & 4 & - & - & 一 \\
\hline 15. IX. & - & - & 3 & - & 22 & 23 & 6 & - & 21 & 9 & 14 & - & 1 & - & - & 1 \\
\hline 29. X. & - & - & 1 & 2 & 26 & 15 & 4 & 3 & 19 & 14 & 5 & - & 6 & - & 4 & 1 \\
\hline 27. VII. & & 12 & & & 49 & & & & 30 & & & & 9 & & & - \\
\hline 25. VIII. & & 8 & & & 42 & & & & 35 & & & & 15 & & & - \\
\hline 15. IX. & & 3 & & & 45 & & & & 36 & & & & 15 & & & 1 \\
\hline 29. X. & & 1 & & & 43 & & & & 40 & & & & 15 & & & 1 \\
\hline
\end{tabular}

III. (cf. Fall 18). Auguste N.

\begin{tabular}{|c|c|c|c|c|c|c|c|c|c|c|c|c|c|c|c|c|}
\hline Datum & M & $W$ & $\mathrm{~T}$ & $2 \mathrm{~K}$ & $2 S$ & $1 \mathrm{~K} 1 \mathrm{~S}$ & $3 \mathrm{~K}$ & $3 \mathrm{~s}$ & $2 \mathrm{~K} 1 \mathrm{~S}$ & $1 \mathrm{~K} 2 \mathrm{~S}$ & $4 \mathrm{~K}$ & $4 \mathrm{~S}$ & $3 \mathrm{~K} 1 \mathrm{~S}$ & $1 \mathrm{~K} 3 \mathrm{~S}$ & $2 \mathrm{~K} 2 \mathrm{~S}$ & $5 \mathrm{~K}$ \\
\hline 27. VII.05 & 1 & 1 & 22 & 4 & 25 & 12 & 7 & 2 & 9 & 8 & 7 & - & 1 & 一 & 1 & - \\
\hline 25. VIII. & - & - & 13 & 3 & 23 & 21 & 10 & - & 19 & 4 & 4 & - & 3 & - & - & - \\
\hline 7. IX. & - & 1 & 11 & 4 & 19 & 20 & 6 & 2 & 23 & 4 & 6 & - & 3 & - & - & 1 \\
\hline 15. IX. & - & - & 3 & 4 & 31 & 12 & 11 & 1 & 21 & 8 & 5 & - & 2 & - & - & 2 \\
\hline 2. XI. & - & - & 5 & 3 & 22 & 18 & 16 & 2 & 17 & 10 & 7 & - & - & - & - & - \\
\hline 13. XI. & - & - & 5 & - & 20 & 16 & 7 & 4 & 20 & 11 & 5 & - & 9 & 1 & 1 & 1 \\
\hline 27. VII. & & 24 & & & 41 & & & & 26 & & & & 9 & & & - \\
\hline 25. VIII. & & 13 & & & 47 & & & & 33 & & & & 7 & & & - \\
\hline 7. IX. & & 12 & & & 43 & & & & 35 & & & & 9 & & & 1 \\
\hline 15. IX. & & 3 & & & 47 & & & & 41 & & & & 7 & & & 2 \\
\hline 2. XI. & & 5 & & & 43 & & & & 45 & & & & 7 & & & - \\
\hline 13. XI. & & 5 & & & 36 & & & & 42 & & & & 16 & & & 1 \\
\hline
\end{tabular}


Die Fälle I-III wollen wir zusammen besprechen. Es handelt sich um drei Fälle von Drüsentuberkulose, welche zur Heilung kamen. Der klinische Verlauf war derart befriedigend, dass wir nach ihm schon von einer vollständigen Heilung überzeugt sein konnten, wenn auch in der Tiefe noch Residuen von den Drüsen zu fühlen waren. Gleichsam als Illustration zu den Fällen führen wir die Blutbildtabellen an, welche in geradezu wunderschöner Weise eine Sanation des Blutes uns vor Augen führen. Besonders deutlich wird uns der Verlauf in der Umgestaltung des Blutbildes, wenn wir für jede Klasse die zusammenfassenden Zahlen geben, wie es in jeder zweiten Tabelle geschehen ist. In diesen sehen wir die Zahl der Leukozyten der ersten Klasse allmählich sich verringern, in der zweiten Klasse nimmt sie nur wenig $a b$, in der dritten und vierten steigt sie allmählich an und tritt in der fünften neu auf. Die zuletzt erhobenen Blutbefunde der drei Fälle weisen ein absolut normales Blutbild auf.

Die nach längerer Zeit von den Patienten erfolgten Nachrichten bezeugen vollständiges Wohlbefinden, wie es nach den Blutbildtabellen auch nicht anders zu erwarten war.

IV. (cf. Fall 20). Frieda P.

\begin{tabular}{|c|c|c|c|c|c|c|c|c|c|c|c|c|c|c|c|}
\hline Datum & M & W & $\mathrm{T}$ & $2 \mathrm{~K}$ & $2 \mathrm{~S}$ & $1 \mathrm{~K} \mathrm{1S} 3 \mathrm{~K}$ & $3 \mathrm{~s}$ & $2 \mathrm{~K} 1 \mathrm{~S}$ & $1 \mathrm{~K} 2 \mathrm{~S}$ & $4 \mathrm{~K}$ & $4 S$ & $3 \mathrm{~K} 1 \mathrm{~S}$ & $1 \mathrm{~K} 3 \mathrm{~S}$ & $2 \mathrm{~K} 2 \mathrm{~S}$ & $5 \mathrm{~K}$ \\
\hline 25.VIII.05 & 一 & $\ldots$ & 7 & 2 & 21 & 10 & 1 & 20 & 8 & 10 & - & 7 & - & - & - \\
\hline 7. IX. & - & - & 6 & 4 & 15 & 14 & 4 & 24 & 9 & 9 & - & 6 & - & 3 & - \\
\hline 3. XII. & - & - & 4 & 4 & 20 & 14 & 3 & 23 & 11 & 7 & -1 & 5 & - & 3 & $\cdots$ \\
\hline
\end{tabular}

Während die anderen Fälle von Drüsentuberkulose klinisch so günstig verliefen, konnte in diesem Falle, wo es sich um recht beträchtliche Drüsenschwellung am Halse handelte, nicht im gleichen Masse Verkleinerung der Drüsen konstatiert werden; während ferner in den Fällen I- III die Blutbildtabellen während der Serumkur ungestört fortschreitende Besserung im Blutleben beweisen, ist in diesem Falle eine Veränderung des Blutbildes nicht erfolgt.

Wir sehen, dass schon vor der Serumbehandlung das Blutbild völlig normal ist, demnach ist hier ein Kreisen von Toxinen im Blute von vornherein nicht anzunehmen. Hieraus müssen wir weiter folgern, dass eine Paralysierung durch das eingespritzte Serum und somit eine Arbeitsleistung des Serums gar nicht stattfinden konnte. Die Drüsen wurden deshalb von dem Serum nicht beeinflusst.

Die Blutbildtabellen dieses Falles drängen ferner zu der Annahme, dass die Tuberkulose sich in einem vollständig inaktiven Stadium befinden musste. Diese Annahme ist uns jetzt nachträglich bestätigt; die Drüsen wurden am 13. I. 06 chirurgisch entfernt und 
Das Blutbild stand schon zu Anfang dem normalen nahe, am 7. IX. kann es als vollständig normal bezeichnet werden. Wenn auch die Schwankung in der Verschiebung nach links am 15. IX. eintrat, so gibt doch ein solcher Blutbefund eine günstige Prognose, wie wir sie auch nach dem klinischen Bilde gestellt haben.

Interessant ist in diesem Falle das Zusammenfallen der Besserung des Blutbildes mit der Serumbehandlung. Patient hatte bis zum 5. IX. 10 Serumeinläufe in den Mastdarm erbalten, ist darauf bis zum 15. IX. ohne Serumbehandlung gewesen. Das Resultat der nun folgenden neun subkutanen Einspritzungen ist leider durch eine Blutuntersuchung nicht kontrolliert, da Patient wegen einer Unbotmässigkeit plötzlich aus der Anstalt verwiesen wurde.

VIII. (cf. Fall 2). Emil M.

\begin{tabular}{|c|c|c|c|c|c|c|c|c|c|c|c|c|c|c|c|c|c|}
\hline Datum & $M$ & $\mathrm{~W}$ & $\mathrm{~T}$ & $2 \mathrm{~K}$ & $2 \mathrm{~S}$ & $1 \mathrm{~K} 1 \mathrm{~S}$ & $3 \mathrm{~K}$ & $3 \mathrm{~S}$ & $2 \mathrm{~K}$ is & $1 \mathrm{~K} 2 \mathrm{~S}$ & $4 \mathrm{~K}$ & $4 \mathrm{~S}$ & $3 \mathrm{~K} 1 \mathrm{~S}$ & $1 \mathrm{~K} 3 \mathrm{~S}$ & $2 \mathrm{~K} 2 \mathrm{~s}$ & $5 \mathrm{~K}$ & $4 \mathrm{~K} 1 \mathrm{~S}$ \\
\hline 7. VII. 05 & - & 3 & 13 & 8 & 23 & 18 & 9 & - & 16 & 3 & 4 & - & 2 & - & 1 & - & - \\
\hline II. & - & - & 18 & 2 & 26 & 20 & 11 & 1 & 14 & 5 & 2 & - & - & - & - & 1 & - \\
\hline 15. IX. & - & - & 12 & 4 & 36 & 14 & 8 & 4 & 10 & 6 & 2 & - & 2 & - & - & - & 2 \\
\hline 2. XI. & - & - & 14 & 7 & 26 & 20 & 9 & - & 15 & 4 & 3 & - & 1 & - & 1 & - & - \\
\hline 3. XII. & - & 1 & 7 & 2 & 21 & 21 & 9 & 3 & 21 & 6 & 4 & - & 4 & - & 1 & - & - \\
\hline
\end{tabular}

Der klinische Verlauf entspricht ganz den Tabellen der Blutnntersuchungen. Es handelt sich um einen unserer günstigst verlaufenen Fälle. Die letzte Tabelle kommt dem normalen sehr nahe.

IX. (cf. Fall 1). Gustav P.

\begin{tabular}{|c|c|c|c|c|c|c|c|c|c|c|c|c|c|c|c|c|c|}
\hline Datum & $\mathbf{M}$ & W & $\mathrm{T}$ & $2 \mathrm{~K}$ & $2 \mathrm{~s}$ & $1 \mathrm{~K} 1 \mathrm{~S}$ & $3 \mathrm{~K}$ & $3 \mathrm{~S}$ & $2 \mathrm{~K} 1 \mathrm{~S}$ & $1 \mathrm{~K} 2 \mathrm{~S}$ & $4 \mathrm{~K}$ & $4 \mathrm{~S}$ & $3 \mathrm{~K} 1 \mathrm{~S}$ & $1 \mathrm{~K} 3 \mathrm{~S}$ & $2 \mathrm{~K} 2 \mathrm{~S}$ & $5 \mathrm{~K}$ & $4 \mathrm{~K}$ \\
\hline 5.7 & - & - & 3 & 1 & 23 & 5 & 5 & 3 & 23 & 19 & 9 & - & 3 & - & 3 & 3 & - \\
\hline 15. IX & - & - & 4 & 2 & 16 & 12 & 14 & 4 & 14 & 18 & 10 & - & 4 & - & 2 & - & - \\
\hline 2. XI & - & - & 10 & 1 & 20 & 11 & 11 & 1 & 17 & 12 & 6 & - & 6 & - & 4 & 1 & - \\
\hline 2. XII. & - & - & 2 & 1 & 17 & 10 & 12 & 3 & 16 & 12 & 9 & - & 8 & - & 4 & 5 & 1 \\
\hline
\end{tabular}

Wir haben vor uns die Blutbildtabellen unseres gesundesten Phthisikers. Abgesehen von der Schwankung $10 \mathrm{~T}$ in der dritten Tabelle, welche vielleicht noch zu den nicht pathologischen gehört, bekunden die Tabellen eine völlig normale Blutbeschaffenheit. Ein kleiner Unterschied gegen früher macht sich bei der letzten Untersuchung geltend, dass nämlich hier ganz besonders viele Leukozyten der vierten und fünften Klasse vorhanden sind. Man dürfte auch auf Grund dieser Tabellen wohl die beste Prognose stellen. 
X. (cf. Fall 22). Erna T.

\begin{tabular}{|c|c|c|c|c|c|c|c|c|c|c|c|c|c|c|c|c|}
\hline Datum & $\mathbf{M}$ & $\mathrm{W}$ & $\mathrm{T}$ & $2 \mathrm{~K}$ & $2 \mathrm{~S}$ & $1 \mathrm{~K} 1 \mathrm{~s}$ & $3 \mathrm{~K}$ & $3 \mathrm{~S}$ & $2 \mathrm{~K} 1 \mathrm{~S}$ & $1 \mathrm{~K} 2 \mathrm{~s}$ & $4 \mathrm{~K}$ & $4 S$ & $3 \mathrm{~K} 1 \mathrm{~S}$ & $1 \mathrm{~K} 3 \mathrm{~S}$ & $2 \mathrm{~K} 2 \mathrm{~S}$ & $5 \mathrm{~K}$ \\
\hline II.05 & - & - & 26 & 3 & 24 & 26 & 5 & - & 7 & 3 & 3 & - & 3 & - & - & - \\
\hline 15. IX. & - & - & 14 & ] & 20 & 28 & 5 & 1 & 13 & 10 & 4 & - & - & - & 2 & 2 \\
\hline $2 . \mathrm{XI}$. & - & 1 & 10 & 2 & 25 & 27 & 5 & 1 & 14 & 7 & 5 & - & 2 & - & - & 1 \\
\hline 13. XI. & - & - & 20 & 3 & 13 & 35 & 7 & 3 & 15 & 2 & - & - & 2 & - & - & - \\
\hline
\end{tabular}

Vergleichen wir diese Tabellen mit der Fieberkurve, auf welcher die Serumapplikationen notiert sind, so sehen wir, dass das Fieber ron Anfang bis 13. IX. dauerte. Während dieser Zeit hat Patientin sieben Injektionen erhalten. Die Untersuchung am 15. IX. zeigt eine auffallende Besserung. Die dritte Untersuchung wurde auf der Höhe des Fiebers bei $39^{\circ} \mathrm{C}$ gemacht, Patientin hatte auf die Einspritzung am 31. X. sehr stark reagiert. Ganz im Gegensatz dazu ist aber das Blutbild noch weiter nach rechts dem normalen zugerückt. Da Patientin so schlecht die Einspritzungen vertrug, so hatten wir von weiterer Serumbehandlung abgelassen. Der letzte Befund am 13. XI. zeigt wieder eine Verschlechterung. Berücksichtigen wir den Anfangsund Endstatus der Lungenuntersuchung', so stehen dieselben denen der Blutuntersuchung so ziemlich in gleichem Verhältnisse.

XI. (cf. Fall 8). Johann M.

\begin{tabular}{|c|c|c|c|c|c|c|c|c|c|c|c|c|c|c|c|c|c|}
\hline Datum & $\mathrm{M}$ & $W$ & $\mathrm{~T}$ & $2 \mathrm{~K}$ & $2 \mathrm{~s}$ & $1 \mathrm{~K} 1 \mathrm{~S}$ & $3 K$ & $3 \mathrm{~S}$ & $2 \mathrm{~K} 1 \mathrm{~S}$ & $1 \mathrm{~K} 2 \mathrm{~S}$ & $4 \mathrm{~K}$ & $4 \mathrm{~S}$ & $3 K$ 1S & $1 \mathrm{~K} 3 \mathrm{~s}$ & $2 \mathrm{~K} 2 \mathrm{~S}$ & $5 \mathrm{~K}$ & $4 \mathrm{~K} 1 \mathrm{~S}$ \\
\hline 27. VII. 05 & 1 & 1 & 28 & 4 & 13 & 20 & 14 & 1 & 12 & - & 2 & - & 1 & - & 2 & 1 & - \\
\hline 25. VIII. & - & - & 16 & 2 & 26 & 16 & 5 & 1 & 12 & 9 & 7 & - & 4 & - & 1 & - & 1 \\
\hline 7. IX. & - & - & 18 & 4 & 20 & 32 & 6 & - & 8 & 12 & - & - & - & - & - & - & - \\
\hline 15. IX. & - & - & 9 & 1 & 34 & 12 & 8 & 2 & 15 & 10 & 2 & - & 5 & 一 & 1 & - & 1 \\
\hline 2. XI. & - & - & 7 & - & 19 & 21 & 2 & 2 & 22 & 12 & 6 & - & 4 & - & 3 & 1 & 1 \\
\hline 3. XII. & - & - & 6 & - & 17 & 29 & 6 & 2 & 20 & 10 & 6 & - & 3 & - & - & 1 & 一 \\
\hline & & & & letz & te & ispri & itzu & & & & & & & & & & \\
\hline 4. I. 06 & - & - & 11 & - & 20 & 17 & 3 & 2 & 15 & 19 & 1 & - & 4 & - & 4 & 1 & 3 \\
\hline
\end{tabular}

Im Vergleiche zu dem klinischen Verlaufe bieten uns diese Tabellen auffällige Befunde. Es handelt sich um einen Patienten, bei dem klinisch keine Besserung eintrat, dessen Temperatur jetzt ein volles Halbjahr ständig abends $38^{\circ}$, an 11 Tagen sogar $39^{\circ}$ überschritt und in letzter Zeit tagsüber zwischen $38^{\circ}$ und $39^{\circ}$ schwankte. Analog klinisch gleich verlaufenen Fällen müsste das Blutbild, nach- 
33] Über 25 mit Marmoreks Serum behandelten Fälle von Tuberkulose.

dem einmal eine solche Schädigung wie am 27. VII. stattgefunden hatte, weiter sich verschlechtern. Ob das Serum den Leukozyten hier tatsächlich zu Hilfe gekommen ist, ist nicht erwiesen, aber mit Wahrscheinlichkeit anzunehmen.

Von rein klinischem Standpunkte aus ist sein relativ gutes Befinden schon längst auffällig. Die letzte Blutuntersuchung ist zwei Monate nach der letzten Einspritzung gemacht und zeigt wieder ein Anwachsen der Leukozytenzahl der ersten Klasse. Im übrigen liegt eine weitere Verschlechterung des Blutbildes noch nicht vor.

XII. (cf. Fall 5). Luigi N.

\begin{tabular}{|c|c|c|c|c|c|c|c|c|c|c|c|c|c|c|c|c|}
\hline Datum & $\mathbf{M}$ & $\mathrm{W}$ & $\mathbf{T}$ & $2 \mathrm{~K}$ & $2 \mathrm{~S}$ & $1 \mathrm{~K} 1 \mathrm{~S}$ & $3 \mathrm{~K}$ & $3 \mathrm{~S}$ & $2 \mathrm{~K} 1 \mathrm{~S}$ & $1 \mathrm{~K} 2 \mathrm{~S}$ & $4 \mathrm{~K}$ & $4 S$ & $3 \mathrm{~K} 1 \mathrm{~S}$ & $1 \mathrm{~K} 3 \mathrm{~S}$ & $2 \mathrm{~K} 2 \mathrm{~S}$ & $5 \mathrm{~K}$ \\
\hline 1.VIII.05 & 2 & 2 & 31 & 10 & 15 & 22 & 6 & -- & 7 & 3 & - & - & 1 & - & 1 & - \\
\hline 25. VIII. & - & - & 22 & 2 & 30 & 14 & 4 & - & 20 & - & 4 & - & 4 & - & - & $\ldots$ \\
\hline
\end{tabular}

Wir hatten im klinischen Teil gesagt: „Das körperliche Befinden war im übrigen gut, Patient erholte sich trotz des andauernden Fiebers. Sein Körpergewicht stieg von 130 anf 140 Pfund. - Bei dem andauernden hohen Fieber müsste man eher eine Verschlechterung als eine Besserung des Blutlebens erwarten. Da Patient erst 14 Tage vor seinem Eintritt in die Anstalt, wie er angab, erkrankt war, so war das Vermögen der Leukozyten, ihre Kerne zu teilen, nicht erschöpft. Nachdem aber das Blutbild in der kurzen Zeit vor der Behandlung eine solche Schädigung erfahren hatte, ist eine so eklatante Besserung des Blutes bei dem andauernden Fieber höchst auffällig. Es ist uns sehr wahrscheinlich, dass hier mit dem Serum durch Zufuhr von Antitoxinen diese Besserung erzielt ist.

XIII. (cf. Fall 6). Walter H.

\begin{tabular}{|c|c|c|c|c|c|c|c|c|c|c|c|c|c|c|c|c|}
\hline Datum & $\mathbf{M}$ & W & $\mathrm{T}$ & $2 \mathrm{~K}$ & $2 \mathrm{~S}$ & $1 \mathrm{~K} \quad 1 \mathrm{~S}$ & $3 \mathrm{~K}$ & $3 s$ & $2 \mathrm{~K} 1 \mathrm{~S}$ & $1 \mathrm{~K} 2 \mathrm{~S}$ & $4 \mathrm{~K}$ & $4 \mathrm{~S}$ & $3 K 1 S$ & $1 \mathrm{~K} 3 \mathrm{~S}$ & $2 \mathrm{~K} 2 \mathrm{~S}$ & $5 \mathrm{~K}$ \\
\hline 3.VIII.05 & 2 & 2 & 8 & 2 & 18 & 19 & 6 & 4 & 18 & 10 & 2 & - & 4 & 一 & 3 & 2 \\
\hline 25.VIII. & - & - & 12 & 1 & 29 & 19 & 4 & 4 & 17 & 8 & - & - & 4 & - & 2 & - \\
\hline
\end{tabular}

Wie im klinischen Verlaufe keine Besserung eingetreten war, so ist auch in den Blutbildtabellen eine wesentliche Veränderung nicht zu konstatieren. 
XIV. (cf. Fall 16). Heinrich A.

\begin{tabular}{l||c|c|c|c|c|c||c|c|c|c||c|c|c|c|c|c}
\hline \hline Datum & $\mathrm{M}$ & $\mathrm{W}$ & $\mathrm{T}$ & $2 \mathrm{~K}$ & $2 \mathrm{~S}$ & 1K 1S & $3 \mathrm{~K}$ & 3 S & 2K 1S & 1K 2S & 4 K & 4 S & 3K 1S & 1K 3S & 2K 2S & 5 K \\
\hline \hline 25.VIII.05 & - & - & 20 & 2 & 26 & 18 & 5 & - & 15 & 10 & 2 & - & 2 & - & - & - \\
7. IX. & - & - & 17 & - & 13 & 20 & 6 & 5 & 20 & 11 & 6 & - & 1 & - & 1 & - \\
15. IX. & - & - & 33 & 1 & 34 & 21 & 4 & - & 6 & - & - & - & - & - & 1 & - \\
18. IX. & - & - & 22 & 2 & 23 & 28 & 5 & - & 13 & 2 & 2 & - & 3 & - & - & -
\end{tabular}

Bringen wir die Blutbildtabellen in Beziehung mit dem klinischen Krankheitsverlaufe, so stehen die Blutbildverschlechterungen trotz der Serumbehandlung mit den klinischen im Einklang. Hier würden Leukozytenzählungen vollständige Klarheit bringen. - Patient verliess verschlechtert die Anstalt und ist, wie wir hören, bereits gestorben.

XV. (cf. Fall 11). Heinrich K.

\begin{tabular}{|c|c|c|c|c|c|c|c|c|c|c|c|c|c|c|c|c|}
\hline Datum & $\mathbf{M}$ & $\mathrm{W}$ & $\mathrm{T}$ & $2 \mathrm{~K}$ & $2 \mathrm{~s}$ & $1 \mathrm{~K} 1 \mathrm{~S}$ & $3 \mathrm{~K}$ & $3 \mathrm{~S}$ & $2 \mathrm{~K} 1 \mathrm{~S}$ & $1 \mathrm{~K} 2 \mathrm{~S}$ & $4 \mathrm{~K}$ & $4 \mathrm{~S}$ & $3 \mathrm{~K} 1 \mathrm{~S}$ & $1 \mathrm{~K} 3 \mathrm{~S}$ & $2 \mathrm{~K} 2 \mathrm{~S}$ & $5 \mathrm{~K}$ \\
\hline 3.VIII.05 & 1 & 1 & 13 & 5 & 18 & 34 & 3 & 1 & 14 & 3 & 4 & - & 2 & - & 1 & 一 \\
\hline 25. VIII. & - & - & 36 & - & 26 & 24 & 2 & 2 & 6 & 4 & - & - & - & - & - & - \\
\hline 7. IX. & - & 1 & 27 & 3 & 23 & 28 & 5 & - & 10 & 3 & - & - & - & 一 & - & - \\
\hline 15. IX. & 1 & 1 & 34 & 2 & 26 & 20 & 6 & - & 8 & 1 & - & - & 1 & - & - & - \\
\hline
\end{tabular}

Die Blutbildtabellen zeigen ein getreues Abbild des klinischen Krankheitsverlaufes. Es war, obwohl die Tuberkulose ziemlich aller Organe sehr vorgeschritten war, mit dem Serum nur ein Versuch gemacht. In solchen Stadien schützt allerdings wohl niemals eine Serumtherapie mehr vor dem Exitus.

XVI. (cf. Fall 9). Heinrich E.

\begin{tabular}{|c|c|c|c|c|c|c|c|c|c|c|c|c|c|c|c|c|}
\hline Datum & $\mathbf{M}$ & W & $\mathrm{T}$ & $2 \mathrm{~K}$ & $2 \mathrm{~S}$ & $1 \mathrm{~K} 1 \mathrm{~S}$ & $3 \mathrm{~K}$ & $3 \mathrm{~S}$ & $2 \mathrm{~K} 1 \mathrm{~s}$ & $1 \mathrm{~K} 2 \mathrm{~S}$ & $4 \mathrm{~K}$ & $4 \mathrm{~S}$ & $3 \mathrm{~K} 1 \mathrm{~S}$ & $1 \mathrm{~K} 3 \mathrm{~S}$ & $2 \mathrm{~K} 2 \mathrm{~S}$ & $5 \mathrm{~K}$ \\
\hline 15. IX. & 2 & - & 27 & 1 & 20 & 39 & 1 & - & 7 & 3 & $\cdots$ & - & - & 一 & - & - \\
\hline 7. X. & 1 & - & 23 & 7 & 27 & 18 & 8 & - & 14 & 1 & 1 & - & - & - & - & - \\
\hline
\end{tabular}

Wir sehen in diesem Falle eine starke Schädigung des Blutbildes, der Hauptteil der Zellen ist in den beiden ersten Klassen untergebracht, ein nur kleiner Teil in der dritten, während die vierte und fünfte bei der ersten Untersuchung vollständig verwaist ist. Das Blutbild ist somit stark nach links verschoben. Es handelt sich hier um eine überaus schnell zum Tode führende Miliartuberkulose. Ganz 
im Gegensatz zu dem klinischen Verlaufe hat sich aber das Blutbild am 7. X. wesentlich gebessert, wir finden weniger Zellen sowohl in der ersten wie zweiten Klasse, dagegen bedeutend mehr in der dritten und sogar einen Vertreter der vierten Klasse. Zur Benrteilung des Falles führen wir die Blutbefunde an, die Arneth bei seinen Fällen von Miliartuberkulose angibt ${ }^{1}$ ).

Fall 1.

\begin{tabular}{|c|c|c|c|c|c|c|c|c|c|c|c|c|c|c|c|c|}
\hline Datum & $\mathbf{M}$ & $\mathrm{W}$ & $\mathrm{T}$ & $2 \mathrm{~K}$ & $2 \mathrm{~S}$ & $1 \mathrm{~K} 1 \mathrm{~S}$ & $3 \mathrm{~K}$ & $3 S$ & $2 \mathrm{~K}$ is & $1 \mathrm{~K} 2 \mathrm{~S}$ & $4 \mathrm{~K}$ & $4 S$ & $3 \mathrm{~K} 1 \mathrm{~S}$ & $1 \mathrm{~K} 3$ & $2 \mathrm{~K} 2 \mathrm{~S}$ & $5 \mathrm{~K}$ \\
\hline 5. I. & - & - & 31 & - & 32 & 28 & - & 1 & 5 & 2 & - & - & - & 1 & - & - \\
\hline 9. I. & -- & 1 & 35 & - & 24 & 32 & - & 2 & 3 & 3 & - & - & - & - & - & - \\
\hline 14. I. & - & - & 29 & - & 27 & 28 & 4 & - & 9 & 3 & - & - & - & - & - & - \\
\hline 18. I. & - & 2 & 40 & 3 & 23 & 27 & 3 & - & 2 & $\ldots$ & - & - & - & $\ldots$ & - & - \\
\hline 18. I. & - & 1 & 41 & 6 & 23 & 22 & 4 & - & 3 & - & - & - & - & - & - & 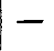 \\
\hline
\end{tabular}

Exitus 19. I.

Fall 2.

\begin{tabular}{r|r|r|r|r|r|r|r|r|r|r||r|r|r|r|r||} 
8. XI. & - & 1 & 30 & 1 & 25 & 21 & 3 & 2 & 11 & 2 & 1 & - & 1 & 1 & 1 \\
14. XI. & 1 & 13 & 53 & - & 13 & 16 & 1 & - & 2 & 1 & - & - & - & - & - \\
\hline
\end{tabular} Exitus 14. IX.

Fall 3.

15. v. $|1|-|39| 2|25| 29|| 1|-| 2|1|-|-|-|-|-\mid-$ Exitus 21. V.

Fall 4.

15. XII. $|-| 3\left|{ }^{3} 4\right||4| 12|29||5|-|-3|-|-|-|-|-\mid-$ Exitus 17. XII.

In den beiden ersten A rnethschen Fällen können wir deutlich eine fortschreitende Verschlechterung des Blutbildes wahrnehmen, Fall 3 zeigt sechs Tage vor dem Tode eine kolossale Schädigung, desgleichen Fall 4 zwei Tage vor dem Tode. Auch in unserem Falle würde sich das Blutbild nach diesen Arnethschen Erfahrungen sicher in ähnlicher Weise gestaltet haben, wie in den angeführten, wenn keine spezifische Beeinflussung der zelligen Elemente des Blutes stattgefunden bätte. Wir denken uns den Vorgang folgendermassen.

Das Blut ist bei Miliartuberkulose mit Toxinen so überladen, dass es zur Bildung älterer Leukozyten im Blute nicht kommen kann.

1) Arneth, Die Lungenschwindsucht auf Grundlage klinischer und experimenteller hämatologischer Untersuchungen. Verlag von Johann Barth, Leipzig. 1905. 
Sobald die jungen Formen einigermassen imstande sind, Antikörper zu bilden, werden diese frei und von den Toxinen paralysiert, worauf die Zellen selbst zugrunde gehen. Kommt es nun, wie in unserem Falle trotzdem zur Bildung älterer Leukozyten, so müssen die Toxine vorher auf andere Weise ausgeglichen sein. Dieses hatte in unserem Falle durch Injektion grosser Mengen des Marmorekschen Serums stattgefunden, Patient hatte fünf, drei und einen Tag vor der Blutentnahme je $10 \mathrm{ccm}$ Serum subkutan erhalten. Trotzdem nun den Zellen von seiten des Heilserums diese Hilfe geleistet wurde, konnte der ungünstige Ausgang nicht abgewendet werden.

Es hat dieses seinen Grund in der bei Miliartuberkulose auftretenden Hypoleukozytose. Arneth hat durch Versuche am Tier nachgewiesen, dass, sobald lebende Gifte, die Krankheitserreger selbstaim Blute kreisen, es zu bedeutender Abnahme der Zahl der Leukozyten kommt. Er bezieht diesen Verbrauch der Leukozyten, denn um einen solchen handelt es sich ja nur, auf die gesteigerte Inanspruchnahme der Neutrophilen im Nahkampfe mit den bazillären Elementen und deren Produkten, den Proteinen. Sobald es sich um eine toxische Schädigung des Blutes handelt, wie z. B. bei der Diphtherie, kommt im Gegenteil eine Hyperleukozytose zustande. Berücksichtigt man bei Miliartuberkulose ausser den im Blute kreisenden Bakterien noch die anderen Ursachen, wie die Bildung von zahllosen Tuberkeln, den Verbrauch von Leukozyten, welcher mit der Sputumproduktion verknüpft ist, so ist die Hypoleukozytose sehr wohl verständlich.

Wenn auch in unserem Falle eine Zählung nicht ausgeführt ist, so zögern wir jedoch nicht, in Analogie anderer Fälle von Miliartuberkulose eine Hypoleukozytose anzunehmen. Diese in Verbindung mit der durch das Serum zwar verminderten, aber durch die Übergewalt der Krankheit zu stark gesetzten qualitativen Schädigung der Leukozyten liess den ungünstigen Ausgang nicht vermeiden, zumal Lunge und Gehirn als lebenswichtige Organe zu sebr ergriffen waren.

\section{Schluss.}

Aus unseren Blutuntersuchungen ergibt sich in den meisten Fällen eine völlige Übereinstimmung im Verlaufe der Vorgänge unter den neutrophilen Leukozyten und dem hlinischen Krankheitsbilde. Es ist bei den günstig verlaufenen Fällen mit den Resultaten der Blutuntersuchung eine weitere Stütze zur Annahme einer wirklichen dauernden Besserung gegeben. Inwieweit diese Besserungen durch die Serumbehandlung bewirkt sind, lässt sich zahlenmässig natürlich nicht feststellen, da bei nicht der Serumtherapie unterworfenen Tuber- 
kulösen fortlaufende Blutuntersuchungen in grösserem Umfange noch nicht gemacht sind. Wohl lässt sich aber vermuten, dass in den günstig verlaufenen Fällen eine bessernde Einwirkung stattgefunden hat. Hauptsächlich unter den chirurgischen Fällen finden wir die schönsten Fortschritte in der Sanierung der Leukozyten, nicht ganz so deutlich hervortretend sind sie bei den Lungentuberkulosen. Es ist uns dieses ein Beweis dafür, dass die Tuberkulose der Lunge oft durch Mischinfektionen kompliziert ist und zur Ausheilung einer bedeutend längeren Zeit bedarf.

Gerade die nicht günstig verlaufenen Fälle von Lungentuberkulose geben uns einen Fingerzeig betreffs der Einwirkung des Serums. Der Fall 8 (XI) musste nach dem klinischen Befunde, besonders bei dem anhaltenden Fieber eine Verschlechterung des Blutbildes aufweisen, zum mindesten aber keine Besserung. Die trotzdem erfolgte günstige Alteration der Leukozyten kann vielleicht ihren Grund darin haben, dass die im Blute kreisenden Toxine der Tuberkelbazillen zum Teil von dem eingespritzten Antitoxin paralysiert sind und so eine Arbeitsentlastung der Neutrophilen stattgefunden hat. Vergleiche dazu auch den Fall 5 (XII).

Noch überzeugender ist der Blutbefund bei der Miliartuberkulose. In diesem Falle wissen wir, wie das Blutbild kurz vor dem Tode beschaffen ist. Eine qualitative Besserung der Leukozyten fün Tage vor dem Tode weist direkt auf ein eingeführtes Agens hin. Es hatten die grossen Serummengen vermocht, Toxine zu paralysieren, so dass die Leukozyten wieder Zeit gewannen, ihre Kerne zu teilen, um Antikörper zu bilden. Der verbessernde Einfluss, die Hypoleukozytose zu heben, ist von dem Serum ohne weiteres nicht zu fordern, da es sich um eine passive Immunisierung handelt, wo der auf die Leukozyten ausgeübte Reiz der aktiven Immunisierung fehlt.

Die Blutuntersuchungen geben uns noch mehr als die klinischen Beobachtungen Veranlassung, einen spezifischen Einfluss des Mar mor ekschen Serums anzunehmen. Die neutrophilen Leukozyten werden im Kampfe gegen die Toxine der Tuberkelbazillen durch das Serum unterstützt, es bleibt ihnen jedoch überlassen, die korpuskulären Elemente, die Bazillen selbst in den zahllosen Tuberkeln zu überwinden resp. sie durch Einschliessung unschädlich $\mathrm{zu}$ machen und die einmal gesetzten Organschädigungen wieder auszugleichen.

Die klinische Brauchbarkeit des Serums wird vielleicht noch gebessert werden, wenn es Marmorek in Zukunft gelingt, bei der Herstellung des Serums diejenigen Ursachen zu eliminieren, die häufig störende Nebenwirkungen machten und gelegentlich zum Aufgeben der Einspritzungen zwangen. 
336 F. Röver: Über 25 mit Marmoreks Serum behandelten Fälle von Tuberk. [38

Wir kommen zu dem Schluss, einmal, dass das Serum in vielleicht noch grösseren Mengen als bisher geschehen, dem Körper zugeführt werden muss, vor allem aber, dass die Serumkur ebenso wie die Tuberkulinkur längere Zeit durchgeführt werden muss, um zu einem sichtbar guten Resultate $\mathrm{zu}$ gelangen. Allerdings gehört zu einer vollständigen Durchführung der Kur eine gewisse Ausdauer und Krankheitseinsicht von seiten der Patienten, auf welche hauptsächlich in Krankenanstalten leider oft nicht zu rechnen ist.

Am Schlusse meiner Arbeit ist es mir eine angenehme Pflicht, meinem hochverehrten Chef, Herrn Direktor Dr. Stöwesand, für die liebenswürdige Unterstützung und Förderung bei Anfertigung dieser Publikation meinen verbindlichsten Dank auszusprechen. 